\title{
TECENDO UM CIRCUITO COMERCIAL A PARTIR DA FEIRA DA MADRUGADA As agenciadoras da moda popular brasileira
}

\author{
André Vereta Nahoum (D) \\ E-mail: andre.nahoum@usp.br \\ Universidade de São Paulo (USP), Departamento de Sociologia, São Paulo - SP, Brasil.
}

DOI: $10.1590 / 3610504 / 2020$

\section{Introdução}

Nas primeiras horas de todos os dias, exceto aos domingos, as ruas e estacionamentos do bairro do Brás, no centro de São Paulo (SP), são tomados por uma miríade de ônibus e vans. Deles desembarcam milhares de revendedoras ${ }^{1}$ de roupas e acessórios. Até as primeiras horas da tarde, elas movem-se rapidamente entre barracas nas ruas e calçadas, shoppings e galerias populares, sempre "atrás da moda”, como diz uma dessas viajantes.

Lojistas, sacoleiras e intermediadores são alguns dos protagonistas de que depende um importante circuito de comércio de itens de vestuário de preço módico que tem no Brás seu polo distribuidor. Produtores e vendedores locais, além de motoristas, guias e carregadores completam a população desse circuito

Artigo recebido em 22/10/2019

Aprovado em 08/03/2020 nacional pelo qual circulam, diariamente, pessoas e mercadorias e milhóes de reais. Esse circuito também gera importantes fluxos digitais. Os celulares e a internet são meios para a disseminação de informações, imagens e mensagens que conectam compradores, transportadores e vendedores situados em diferentes localidades. Esses meios são instrumentais para ampliar o apelo da região e suas roupas. Não substituem, porém, o movimento físico de mercadorias e símbolos promovido por um grupo de comerciantes, em sua maioria mulheres.

O objetivo deste artigo é apresentar fragmentos desse circuito de moda popular e sua organização subjacente, pondo em evidência suas protagonistas, seus trabalhos e os sentidos que a eles atribuem nas definições que oferecem de sua situação. Esses fragmentos foram apurados por meio de uma etnografia dos estacionamentos que recebem ônibus e vans, das áreas de descanso e dos cafés adjacentes. Nesses espaços foi possível estabelecer contatos com motoristas, 
guias, consumidoras, carregadores e representantes de lojas do Brás, bem como de controladores de acesso e funcionários de empresas de transporte. Com base nas relaçóes mantidas com guias e motoristas, realizei 28 entrevistas semiestruturadas e conversas informais com suas clientes, compradoras de roupa da região. ${ }^{2}$ O roteiro recobria percepçóes sobre o Brás e a descoberta da região, a definição que davam à sua situação e questôes relativas aos arranjos de negócio, pontos e atividades de venda, à trajetória ocupacional e ao ciclo de vida, assumindo que padróes de percursos importam nessas definiçôes. Tratava-se, portanto, de restituir os sentidos que a atividade tem para as agentes, em seus termos e figuraçóes, com base em seus anseios e no interior de trajetórias ocupacionais e narrativas biográficas. ${ }^{3}$

Procurei ampliar a escala de análise, visitando diferentes estacionamentos e conversando com passageiras de ônibus procedentes de seis estados (Mato Grosso do Sul, Minas Gerais, Pernambuco, Rio de Janeiro, Rio Grande do Sul e São Paulo) para encampar, na maior medida possível, a diversidade nessa população. Também procurei incluir nas entrevistas perfis diferentes: compradoras iniciantes e veteranas, que consideram a atividade como principal ocupação ou que a tem como instrumento de complementaçáo de renda, uma produtora de adereços de unhas que vem ao Brás para vender e duas "laranjas", pagas para transportar mercadorias para a região. Entrevistei, ainda, figuras de apoio para melhor compreender as atividades: treze guias, motoristas, controladores de acesso aos estacionamentos e funcionários das empresas de transporte, em um total de 44 entrevistas.

A despeito de sua importância para a economia da cidade e do país, trata-se de um circuito sobre o qual pouco se sabe. Os estudos sobre mercadores migrantes no Brasil utilizam como chave analítica comum as categorias normativas do informal, ilegal e ilícito, com que procuram ser registrados, mas que desafiam (Pinheiro-Machado, 2008; Ribeiro, 2010; Telles e Hirata, 2010). Também centram seu olhar nas negociaçóes com os dispositivos de controle e segurança que explicam sua tolerância em meio a informalidade e ou ilegalidade (Pires, 2011; Rabossi, 2011). Embora centrais a esse circuito, esses aspectos não o esgotam nem se aplicam a uma parcela significativa das revendedoras, que possuem lojas e não experimentam esses dispositivos de controle.

Este artigo desloca o olhar para as atividades de compra e revenda de roupas e suas protagonistas. Com isso, contribui para o debate sociológico sobre práticas e representaçóes do engajamento feminino no trabalho por conta própria e sobre comerciantes itinerantes em geral, desafiando as representaçôes que a literatura aponta para essas atividades. Argumento que, ao tecer esse circuito comercial, lojistas e sacoleiras costuram também as tramas de um percurso pessoal, com uma considerável identificação com a atividade comercial. A atividade é frequentemente relacionada, nos discursos, com desejos de autonomia e orgulho pelo reconhecimento da habilidade como boa vendedora por si e por outros.

Nesse sentido, neste artigo dialogo com os estudos sobre o papel de trajetórias ocupacionais para a definiçáo da identidade (Dubar, 1991). Porém, estendo a reflexão para além de trajetórias socioprofissionais conformadas por projetos de carreira definidos pela relação salarial formal, no interior de empresas, domínio clássico desses estudos. Outros caminhos indicam, na literatura, desvios do pretendido, crise e desidentificação por parte de seus agentes, visão que é corroborada por estudos sobre o trabalho por conta própria e ambulante.

$\mathrm{O}$ reconhecimento pelas agenciadoras de um potencial de autonomia e realizaçáo na atividade comercial desafia as representaçóes a respeito dessas ocupaçôes indicadas pela literatura, sobretudo entre mulheres, sugerindo diferenças contextuais e transformaçôes sociais ainda pouco exploradas. Esses estudos apontam que essa atividade aparece como uma alternativa para a obtenção de renda que se impóe aos atores sob força da necessidade, um arranjo precário de sobrevivência diante da exclusão do desejado assalariamento formal (Cattani, 1996; Malaguti, 2001; Pinheiro-Machado, 2004). O trabalho feminino por conta própria, ainda que aquele realizado sob um sistema de venda direta, foi também compreendido como um reflexo de precarização e flexibilização do trabalho em atividades que camuflariam, sob a promessa de autonomia, seu caráter de trabalho subordinado (Abílio, 2014). No caso das agenciadoras da moda popular do Brás, como procuro demonstrar, 
a atividade figura nas suas formulações não apenas como crucial para obter renda e garantir o bem-estar do grupo doméstico como também para prover um sentido de realização pessoal associado a atributos da atividade.

Esse desafio ao conhecimento estabelecido aponta para novas representaçôes em torno de ocupações das mulheres. As desvantagens das mulheres no mercado de trabalho, que estão mais sujeitas a formas de trabalho consideradas precárias (Araújo, 2012; Guimarães, Brito e Barone, 2016), ao desemprego e à inatividade (Guimarães e Brito, 2009) e que conjugam suas ocupaçóes com a maior parte do trabalho doméstico não remunerado (Medeiros e Pinheiro, 2018), podem ajudar a explicar a opção pelo comércio como recurso para obtenção de renda. As limitadas oportunidades e a flexibilidade proporcionada pelo trabalho de vendas foram entendidas pela literatura (Abílio, 2014; Biggart, 1989) como um fator de apelo e explicação da forte presença feminina, mas, neste caso, as viagens de compra dificultam a conciliação da atividade com tarefas domésticas. Tanto que as mulheres são, ainda, excepcionais nos estudos sobre sacoleiros (Pinheiro-Machado, 2004; Rabossi, 2011). Ademais, a limitação de oportunidades no mercado de trabalho não é suficiente para dar conta do sentido de realização pessoal conferido à atividade. A ocupação não é, em seus discursos, justificada pelo estreito horizonte de oportunidades de ocupaçóes conferidas às mulheres. Ao contrário, em alguns casos, é preferida ao emprego formal.

Esse reconhecimento é atrelado ao êxito e ao domínio de competências específicas para tanto. É fundamental, portanto, para explicar os sentidos da atividade, compreender como se produzem, por erros e acertos, competências e disposiçôes localmente e que relação guardam com o contexto de interaçóes. Não basta, como pretende a sociologia dos mercados inspirada pelos estudos sociais da ciência e tecnologia (Callon e Muniesa, 2003), investigar os dispositivos que distribuem capacidades de cálculo e juízo aos participantes de mercados - uma distribuição desigual entre as participantes. É necessário repor a especificidade etnográfica das formas de avaliação, as formas ordinárias de cálculo dependentes de cenas e relaçôes sociais em que se aplicam (Weber, 2002) e de conhecimento local (Geertz, 1978) de que dependem o êxito dos agentes.

Visando a contribuir com esses debates, este artigo descreve como as agenciadoras desenvolvem suas atividades, quais as especificidades simbólicas com que representam a atividade e seu lugar em seu percurso de vida e trajetória ocupacional, quais as competências que definem as chances de êxito, como as adquirem e como se define e difunde a moda que comercializam.

\section{Do Brás ao Brasil: o circuito e suas agenciadoras}

Como outros segmentos da indústria de vestuário, o circuito centrado no Brás depende de uma organização em que atores exercem papéis definidos: desenhistas, modelistas, estampistas, costureiros, distribuidores, vendedores, intermediários e promotores dos símbolos dessa moda (Giusti, 2009). Ainda que este artigo enfoque um fragmento desse universo denso de relaçôes, isto é, as protagonistas responsáveis pela distribuição e comercialização em território nacional das roupas ali adquiridas, alguns outros aspectos do circuito são fundamentais para compreender a atividade e o sentido que tem para essas revendedoras. ${ }^{4}$

O Brás é há muito conhecido por seu comércio acessível de roupas, como atestam várias consumidoras que frequentam a regiāo há décadas. Maria de Fátima não deixa de ir ao Brás ao menos mensalmente há trinta anos. Ali encontramos filhas de sacoleiras em atividade, como Maria, paga para transportar mercadorias para a regiáo.

$\mathrm{Na}$ última década, somaram-se às tradicionais confecçôes e lojas milhares de barracas nas ruas que vendem durante a madrugada. A expansão das atividades comerciais para as primeiras horas do dia deu-se em razão da grande afluência de ônibus e vans que traziam compradores e chegavam antes da abertura das lojas. Percebendo esse fenômeno, produtores de roupas com oficinas no entorno, em especial de origem andina, passaram a oferecer suas mercadorias a esses visitantes nas ruas. Logo depois, as barracas ocuparam também um pátio de manobras ferroviárias abandonado - o Pátio Pari. Para tais produtores, até então subcontratados da 
indústria têxtil, era uma oportunidade de aumentar seu retorno com a venda direta (Aranha, 2017). Em razão do horário de atividades, esse espaço passou a ser conhecido como Feira da Madrugada, atraindo milhares de consumidores diariamente, mas também conflitos com a administração municipal e com grupos que concorrem pela organização do espaço nas ruas e no Pátio (Vereta-Nahoum, 2019). Tanto o crescimento dos visitantes diários quanto os conflitos promoveram a abertura de galerias e shoppings populares na região, além de sucessivas tentativas de formalização dos comerciantes e reorganização do espaço. Atualmente, a Feira da Madrugada refere-se ao conjunto de atividades comerciais desenvolvidas até o final da manhã nessas múltiplas configurações no Brás.

Além do escoamento da confecção local, o Brás tornou-se um importante polo de distribuição de roupas e acessórios chineses. Esse desenvolvimento é um caso exemplar do papel de comunidades transnacionais nas transformações de atividades urbanas (Schiler e Çaglar, 2010), pois deve ao estabelecimento de migrantes e descendentes de chineses que mobilizam laços étnicos na importação de bens e à presença de imigrantes andinos envolvidos em arranjos produtivos têxteis que englobam a subcontratação transnacional de força de trabalho (Freitas, 2013). ${ }^{5}$

Como centro produtor de grandes volumes de roupa, marcado pela ampla disponibilidade de trabalhadores habilidosos e de relativo baixo custo, o Brás poderia ser comparado a outros centros que se tornaram bases de produçáo subcontratada para marcas estrangeiras, à medida que a indústria de vestuário de giro rápido, ainda muito dependente de mão de obra operadora de máquinas, abandonava países avançados em busca de competitividade (Doeringer e Crean, 2006; Entwistle, 2000; Reinach, 2005). A subcontratação e o desenvolvimento da chamada fast fashion ${ }^{6}$ sem dúvida explicam a reprodução do Brás como um dos mais importantes espaços de confecção do continente. Há, porém, importantes diferenças no circuito formado pela Feira da Madrugada. Não só se abastece do circuito de roupa de baixo custo exportada por meio dos grandes mercados do sudeste chinês (como em Yiwu e Guangzhou), sendo importador, como seu desenvolvimento está ligado à substituição de arranjos de subcontratação para empresas de fast fashion pela venda direta a consumidores e revendedores de pequeno e médio porte para o mercado nacional, com o que ganha uma relativa autonomia.

O circuito conformado pela Feira da Madrugada e os múltiplos pontos de venda mantidos pelas revendedoras ao redor do Brasil reproduzem algumas características próprias da fast fashion, com preços ainda mais baixos do que os praticados pelas marcas globais. Os modelos têm um giro muito rápido, aspecto destacado pelas revendedoras, e conformam tendências próprias, com uma estética que é apreciada ao redor do país. Os modelos não são baseados diretamente no prêt-à-porter, mas em peças observadas em programas televisivos, especialmente novelas, vídeos musicais e plataformas digitais, como YouTube e Instagram. ${ }^{7}$ Adaptam-se essas tendências e modelos para formar o que se chama, localmente, de "modinha" que, por sua vez, conforma tendências no resto do país. As plataformas digitais e meios de comunicaçáo eletrônica por celulares também atuam como veículos de difusão dessas tendências e produtos, reduzindo a incerteza que envolve produção, comercialização e consumo desses bens (Kawamura, 2005). Há um conjunto de mulheres que se dedicam a promover a moda do Brás em meio virtual, utilizando-se de contas no YouTube e no Instagram. ${ }^{8}$ Também existem programas vespertinos na televisão brasileira que informam sobre as oportunidades que a região oferece para se vestir como atrizes e celebridades.

Com novos meios logísticos para distribuição de bens, crescimento urbano e tecnologias de comunicação eletrônica, comerciantes móveis, tradicionalmente suspeitos por introduzirem o desconhecido nas comunidades, poderiam estar em vias de extinção (Fontaine, 1993). Mercados de rua também perderiam espaço na economia contemporânea, a menos que lograssem afirmar sua singularidade e a de seus produtos (La Pradelle, 2006). Esse não é, certamente o caso de roupas produzidas em massa e de baixo custo. O consumo de itens de vestuário é, atualmente, realizado em intervalos temporais curtos, seguindo os rápidos giros da fast fashion (Crane e Bovone, 2006), em tentativas de adequação a tendências coletivas e expressão subjetiva (Simmel, 1957), importando relativamente pouco 
em orçamentos familiares. Na última Pesquisa de orçamentos familiares de 2017-2018, os gastos com vestuário representavam, em média, $4,3 \%$ da renda mensal familiar (equivalendo a $\mathrm{R} \$ 160,25$ ), variando de $4,2 \%$ a $2,4 \%$, de acordo com classes de renda (IBGE, 2019a).

Considerando a disponibilidade de meios eletrônicos de compra e pagamento, esse circuito poderia já ter eliminado seus espaços físicos de venda e suas intermediárias. No entanto, a realidade desafia a racionalidade escolástica. $\mathrm{O}$ circuito de moda popular brasileiro continua tendo no Brás seu principal nódulo de distribuição e dependendo da mobilidade de um grupo de comerciantes que transportam bens e símbolos consigo. Em vez de substituir os espaços físicos e agentes desse circuito, novas tecnologias o alimentam.

O trabalho das agenciadoras da moda popular segue variações de uma rotina assim composta: viajar para São Paulo, circular durante madrugada e manhã pelo Brás escolhendo as peças que vão adquirir, levar as peças para os ônibus ou acertar com carregadores para que o façam, retornar às suas cidades de origem, informar às clientes sobre a chegada de novas peças ou dispô-las em suas lojas e vender. Essa sequência é repetida entre uma vez por semana e algumas vezes por ano. É assim que grande parte das peças de vestuário e acessórios comercializados no Brás chegam a consumidores espalhados por todo o país.

Para abastecer seus negócios, algumas mulheres percorrem ainda, a depender de suas cidades de origem e ramos com que trabalham, outros centros comerciais de vestuário em cidades como Goiânia (GO) e Caruaru (PE), bem como polos de malharia de Monte Sião (MG) e de têxteis para casa em Santa Catarina. O Brás é inquestionavelmente considerado, por elas, o circuito com maior variedade e menor preço, o que nem sempre indica melhor qualidade, mas melhores condiçôes de retorno.

Há, ainda, movimentos no sentido inverso do fluxo, com pessoas que vão ao Brás com mercadorias próprias ou de terceiros. É o caso de Nágila, de Franca (SP), que comercializa adesivos de joias para unhas, e de muitos conterrâneos que vendem sapatos. Também é o caso de pessoas que transportam ao Brás bens introduzidos no país sem fiscalização alfandegária.
Ao contrário do que ocorre em outros circuitos que envolvem comerciantes itinerantes, como os analisados por Pinheiro-Machado (2004) e Rabossi (2011), trata-se de uma atividade fundamentalmente realizada por mulheres. Tão rara é a presença masculina entre viajantes de compras no Brás, que um grupo de Alfenas (MG), majoritariamente masculino, é conhecido na região como "ônibus dos homens". Se em outros circuitos são os homens que viajam, enquanto as mulheres permanecem nos pontos de venda, aqui a situação é inversa: quando o empreendimento é conjunto, a mulher é quem viaja, mesmo tendo outra ocupação, enquanto os homens permanecem na loja, como é o caso de Talita. Essa inversão é explicada pela comum associação do domínio dos códigos estéticos subjacentes ao valor e à qualidade das roupas ao universo feminino. Essa figuração sexista garante às mulheres um domínio quase exclusivo, se não sobre a produção, ao menos sobre a circulação e a troca da moda popular, constituindo uma base para a obtenção de recursos materiais e simbólicos, como observado em outras sociedades e períodos históricos (Weiner e Schneider, 1989).

Aos homens que povoam esse circuito são reservados segmentos específicos e atividades de apoio. Dentre os entrevistados, apenas dois vinham ao Brás para adquirir bens: um representando lojas de sua região com pedidos específicos e outro para comprar peças de marcas esportivas consagradas. Os passageiros do "ônibus dos homens" também se especializam no ramo de roupas esportivas, em especial em réplicas de marcas internacionais, que revendem no comércio de rua de sua cidade. A marca funciona, nesses casos, para reduzir a incerteza sobre o bem.

Nas funçóes de apoio, ademais, são os homens que dominam: entre motoristas, carregadores, controladores de acesso aos estacionamentos e encarregados das empresas de transporte, eles são a maioria. Entre os treze entrevistados nessas funçôes, onze são homens. A mais diversa das funçôes é a de guia, na qual se encontram homens e mulheres. Guias oferecem informaçôes sobre oportunidades de compras no Brás, promovendo algumas lojas, e sobre serviços de apoio disponíveis (restaurantes, locais de descanso e asseio); ocasionalmente dão conselhos de negócios. Entre as guias, porém, é comum acumular a função 
com a de revendedora. Muitas tornam-se guias em virtude do conhecimento que ganharam da regiáo como compradoras, caso de Samaya.

Afora o fato de serem majoritariamente mulheres, as agenciadoras da moda popular compóem um grupo significativamente heterogêneo. Variam em sua idade (de 20 a 60 anos), posiçáo social, arranjos e modelos de negócio. Há proprietárias de lojas médias e grandes, algumas das quais viajam de avião e hospedam-se em hotéis da região, indicando uma posição social mais elevada. Há, por outro lado, quem tenha estado em ocupaçóes socialmente pouco prestigiosas, como a de doméstica, e vendedoras de rua. Algumas revendem roupa como atividade secundária, para ajudar parentes ou complementar a renda que obtêm do emprego formal, mas muitas o fazem como sua principal atividade, sendo a mais importante fonte de renda familiar. Das 28 sacoleiras entrevistadas, nove exercem outras ocupaçóes, principalmente nas áreas da educação, com duas professoras e uma administradora, e de serviços estéticos, com três cabelereiras e manicures. Em alguns casos, vendem outros bens além de roupas, em especial cosméticos. Apenas dez são as entrevistadas que contam com familiares com empregos formais que contribuem com a renda familiar: nove têm maridos e uma tem um filho que ajudam. A viabilidade financeira das viagens depende de um capital de giro em torno de 2 mil a 3 mil reais por viagem, de acordo com algumas entrevistadas. Logo, as classes de renda mais baixas estão excluídas da atividade.

Com seu movimento comercial, essas revendedoras conectam o mundo da cidade grande, marcado por ritmos velozes, anonimato, impessoalidade, interaçôes econômicas e encontros ambíguos e até antagônicos, ao mundo das comunidades locais, marcado por relaçóes contínuas de proximidade, vizinhança, parentesco e clientela. Trazem consigo e domesticam o mundo distante que se vê em meios digitais. Diferentemente do caixeiro-viajante descrito por Fontaine (1993) que, realizando um movimento de objetos e ideias novas das cidades para vilarejos, era sempre um estranho rodeado de suspeitas, sacoleiras e lojistas estão inseridas em laços locais nas cidades onde comercializam, domesticando novidades.
No Brás, sua estada é breve, imbuída de um forte etos capitalista e objetivamente direcionada a negociar as mercadorias e trocar mensagens por celular com clientes potenciais. A escassez de tempo é frequentemente ressaltada pelos presentes. Como ouvi diversas vezes de sacoleiras movendo-se agilmente com seus carrinhos, ali "tempo é dinheiro", e todos procuram formas de ganhar. O tempo é escasso sobretudo para aquelas que concentram suas compras nas ruas, durante a madrugada. É o caso de Rafaela (2018), que diz: "50\% da minha compra é Feirinha [...]. Se o ônibus chega tarde por algum problema, você perdeu". Além do ritmo, o movimento nesse espaço é marcado por um constante estado de alerta em razão do risco percebido de roubos e furtos. As transaçóes ali são majoritariamente realizadas em papel-moeda, pois os vendedores cobram sobretaxas pela utilização de cartóes. O sentimento de insegurança quanto ao dinheiro e as mercadorias é, aliás, sua principal queixa quando interrogadas especificamente sobre o espaço de transaçóes. Alijadas das disputas entre comerciantes e poder público pelos usos desse espaço, raramente póem em questão as características do espaço e a natureza de suas transaçóes. Os conflitos só emergem para as revendedoras quando há fechamentos e mudanças infraestruturais que as impedem de fazer suas compras ou as obrigam a compreender a nova distribuição espacial. ${ }^{9}$

Os encontros entre compradores e vendedores soem ser pontuais e ocorrem em meio a desentendimentos, indiferença e até xenofobia. O ritmo do movimento e a permanente rotatividade dos seus participantes mantêm a impessoalidade das relaçóes, impedindo o surgimento de laços de solidariedade, afetos não mercantis ou confraternização. Vendedores asseguram não ter muitos clientes fixos. As consumidoras, por sua parte, explicam que, por estarem sempre procurando produtos diferentes e melhores preços, raramente cultivam relaçóes duradouras com fornecedores. Há um sentimento de que, no mercado, cada agente é equivalente e indiferente ao conjunto das transaçóes. Rafaela (2018) bem revela essa sensação de dissolução numa massa de equivalentes, que garante a liberdade de entrada a qualquer um no mercado, mas também uma indiferença generalizada: "Aqui eu me sinto [apenas] mais uma. Se eu vim, estou. Se eu não vim, eu não vou 
fazer falta". Essas visitantes também lamentam o mau atendimento que recebem de vendedores. Cristina, que acumula a ocupação com o trabalho na malharia de seus pais, contrasta a indiferença com que é recebida em boxes, barracas e lojas com o cuidado que sua família tem no atendimento a seus clientes. Há, ainda, uma forte desconfiança com relação aos migrantes que habitam o Brás, confirmando que mobilidades não importam em uma efetiva comunicação ou em uma atitude cosmopolita, como observa Hannerz (1996).

Em suas cidades de origem, comercializam as roupas adquiridas no Brás em uma variedade de arranjos e modelos de negócio, mal apreendida pela generalidade das categorias "sacoleira", "lojista" e "comerciante" com que se reconhecem. Há desde sacoleiras que vendem em casa até proprietárias de lojas de tamanho considerável (uma entrevistada fala em 130 metros quadrados), que chamam "magazines", no centro de suas cidades. Há também proprietárias de mais de uma loja que vão ao Brás para repor estoque. Entre esses extremos, entretanto, encontramos muitas lojistas que eram sacoleiras e abriram pequenos pontos de venda próximos às suas residências. Essas lojas seguem diferentes modelos de negócio. Há atacadistas, lojas de preço único e varejistas. Em geral, vendem não apenas roupas como também acessórios, bolsas, perfumes e brinquedos. Embora sempre comercializando peças de giro veloz que compóem o que chamam "modinha", muitas especializam-se em alguns nichos: roupa infantil, tamanhos grandes (plus size), esportivas ou moda evangélica.

Esses dados são importantes para diferenciar experiências aqui descritas de outras envolvendo trabalhadoras por conta própria (Abílio, 2014) e sacoleiros (Pinheiro-Machado, 2004). Como essas mulheres não representam marcas nem integram um sistema de vendas diretas, não há aqui uma subordinação camuflada de autonomia nem um obscurecimento do trabalho como acesso ao consumo de roupas. As entrevistadas reconhecem o caráter laboral, separando-o de compras que fazem para si, familiares e amigos, e têm estimativas de custos e ganhos. Ademais, a informalidade, categoria-chave nos estudos sobre trabalhadoras itinerantes, embora presente, não é regra. Além das proprietárias de lojas (dezoito), muitas com registro legal, há distribuidoras por atacado registradas para poder emitir notas fiscais, sem as quais os bens não podem circular pelo país. Cinco entrevistadas apenas não possuem ponto fixo, vendendo nas casas das clientes ou atendendo apenas a encomendas. Entre as vendedoras de rua (duas), há aquelas que se constituíram como microempreendedoras individuais, ainda que não necessariamente tenham sua situação cadastral regular, condição da qual depende o exercício regular do comércio em espaços públicos urbanos em muitas cidades. ${ }^{10}$

Em todos os casos, no âmbito de suas atividades de venda, cultivam os encontros com sua clientela, dos quais depende sua habilidade de oferecer produtos que correspondam às demandas e aos gostos de seus clientes. É por meio dessas relações pessoais que localizam a moda popular. O desafio de singularizar o que é massificado corresponde à principal competência de que depende o êxito no negócio. Antes de tratar de como se constroem essa e outras competências, vale explorar o significado da atividade nas definições de si e de sua situação que fazem essas agenciadoras.

\section{A dignidade da mulher empreendedora}

Compreender o sentido da atividade nas experiências biográficas exige um esforço duplo, correspondente à identificação da classificação de situaçóes com que se descrevem trajetórias singulares e à sua contraposição a percursos paradigmáticos que traduzem pretensóes normativas. Os sentidos de uma atividade social são construídos intersubjetivamente com base em aspiraçôes e frustrações pessoais e também em pretensóes normativas que a sociedade projeta sobre indivíduos de grupos determinados. Assim, projetos que dão sentido à experiência biográfica, gerando sentimentos de realizaçáo pessoal e dignidade na atividade, dependem tanto de aspiraçóes pessoais como dessas expectativas sociais (Dubar, 1991).

Há duas figuraçôes sociais em jogo que podem influenciar as definições biográficas construídas em torno do envolvimento na atividade de revenda de roupas e acessórios. A primeira corresponde às pretensões a respeito da participação das mulheres na economia; a segunda refere-se às representaçóes 
em torno do trabalho por conta própria e do microempreendedorismo.

A despeito de sua entrada no mercado de trabalho em ritmo acelerado na segunda metade do século XX (Guimarães, Brito e Barone, 2016), por muito tempo, o lugar das mulheres no mercado foi considerado excepcional e secundário (Duarte, 1986; Telles, 1992). Seu papel primeiro seria garantir a manutenção da casa e da família contra as ameaças de sua dissolução. Essa figuração demarcou, por muito, os limites de seu envolvimento com atividades econômicas. Forte evidência de sua eficácia é o fato de que, em situaçóes de necessidade, as mulheres recorriam primeiro a atividades que pudessem realizar em seu domicílio. Lançavam-se ao mercado em eventos em que os homens não logravam garantir o bem-estar do grupo. Nesses casos, porém, o trabalho não ganhava muita importância em sua trajetória pessoal e era visto como algo transitório, a menos que a mulher fosse a única responsável pelo grupo (Telles, 1992). Na década de 2000, esse lugar simbólico ainda era reafirmado para justificar a excepcionalidade da presença feminina no circuito comercial que conectava Ciudad del Este (Paraguai) a Porto Alegre (RS) (Pinheiro-Machado, 2004).

Como se sabe, essa figuração a respeito do papel da mulher não bloqueou, mas condicionou suas oportunidades de engajamento no mercado. Ser mulher é um fortíssimo determinante no engajamento em tipos de trabalho associados à maior precariedade, como o trabalho doméstico (Guimarães e Brito, 2009). Elas também foram mais sujeitas ao desemprego e à transição para a inatividade em meio à reestruturação econômica da década de 1990, ao longo do intenso aumento da taxa de atividade feminina (Guimaráes, Brito e Barone, 2016). Ademais, seu envolvimento - ou o reconhecimento público desse envolvimento - no trabalho por conta própria era bastante excepcional (Guimarães e Brito, 2009). Por tudo isso, a atividade comercial, sobretudo, envolvendo o movimento constante, desafia o conjunto de possibilidades ocupacionais reservado às mulheres até recentemente.

Nesse mesmo período, o emprego formal permanecia a referência normativa da definição de trabalho e o modo predileto de atividade econômica (Telles, 2001). Além de ser capaz de produzir uma identidade ocupacional portadora de direitos, o emprego registrado era valorizado pela estabilidade dos rendimentos. $\mathrm{O}$ trabalho por conta própria e o microempreendedorismo seriam, por oposição, interpretados negativamente, equacionados com precariedade e considerados uma alternativa de sobrevivência (Malaguti, 2001). Mesmo em período mais recente, a adesão a essas formas de ocupação foi atribuída a mudanças estruturais que restringem as oportunidades de vínculos formais de emprego e afetam, em particular, as mulheres (Abílio, 2014).

Não é assim, porém, que as revendedoras de roupa pensam a atividade em suas trajetórias pessoais, como definem as razóes de seu envolvimento e seu lugar em relaçáo a pretensôes ocupacionais. Um procedimento comum para auferir o sentido de práticas sociais na construção da identidade é investigar os termos utilizados em relatos biográficos para se referir a elas. Essa prática investigativa supóe que, quando um projeto dá sentido a um percurso biográfico, aparece na definição da situação com formas linguísticas próprias que, acionadas, geram um reconhecimento mútuo dos agentes nela envolvidos e uma identidade comum (Dubar, 1991). Foi assim, aliás, que se procurou compreender tradicionalmente no Brasil os sentidos construídos em torno do trabalho e da atividade econômica em projetos biográficos (Guimarăes, Demazière e Kurumi, 2009; Lobo, 1989; Telles, 1992). No caso das comerciantes viajantes, as categorias linguísticas mobilizadas por elas e para se referir a elas demarcam, antes, diferenças. Lojistas, sacoleiras, comerciantes e até empreendedoras são termos utilizados que indicam diferenças de definição, mas sobretudo a considerável heterogeneidade nos modos de exercício da atividade que também geram rusgas e animosidades. São, afinal, concorrentes, e é comum ouvir de proprietárias de lojas formalizadas queixas às sacoleiras, por não se sujeitarem aos custos tributários e trabalhistas. Assim, não há uma categoria comum mobilizada para definir sua situação e com que se identifiquem nem há um sentimento de pertencimento a uma coletividade dotada de uma identidade comum.

Entretanto, os discursos dessas comerciantes expressam um forte sentido de identificação com esse conjunto de arranjos em que se exerce a atividade, 
o que permite afirmar que produz um sentido de dignidade. Tal identificação aponta para mudanças simbólicas significativas a respeito do envolvimento feminino no mercado, em especial em atividades comerciais. $\mathrm{O}$ sentido que extraem da atividade não se esgota em seus produtos materiais, mas se associa também à autonomia e ao acesso a um universo de socialização amplo, que está além do âmbito doméstico e familiar. Esses sentidos são corroborados pela decisão de muitas mulheres de continuarem comerciantes mesmo tendo ocupaçóes formais. Nas entrevistas, é possível distinguir analiticamente cinco sentidos conferidos à revenda de roupas que explicam seu papel na construção identitária e a dignidade que reconhecem nessa atividade: o cumprimento de um ideal de obrigação, o retorno financeiro, o ideal de autonomia no trabalho por conta própria, os gostos pela venda e pela moda, que conformam uma identidade de ofício, e o ideal de circulação na cidade grande e suas oportunidades de socialização.

\section{"Ideal de obrigaçáo": comércio como provedor de meios materiais de cuidado}

É verdade que algumas revendedoras de roupas atribuem a entrada na atividade à necessidade material. Mas se trata de uma necessidade particular: a de prover condiçôes materiais confortáveis e cuidados ao grupo doméstico, em situaçóes em que decidiram abandonar seus companheiros. A atividade também é associada à capacidade de manter digna e autonomamente o grupo doméstico ao se emancipar de um mau parceiro. Nessas circunstâncias, o trabalho ganha ênfase na trajetória pessoal.

Rose (2018) e Dilma (2018) narram uma trajetória que consideram bem-sucedida, enfatizando sua capacidade de oferecer bem-estar material e cuidado ao grupo doméstico por meio da revenda de roupas:

Depois vem filho... Você trabalha, cuida de filho... Não tem tempo de estudar. [...] Eu casei jovem, [com] 16 anos, daí você tem filho, se separa do marido, aí você tem que se virar. E eu fui uma mulher que não dependi de marido para nada. Eu não pedi pensão, sabe, para não ter o homem enchendo o saco na porta da sua casa. Eu fui assim, independente. [...] Quando a mulher quer ser livre, não ter ninguém perturbando, você tem que sobreviver. [Antes sobrevivia] como camelô. E muito bem. Porque nunca faltava. Tinha todo dia o dinheiro do pão, do leite, do arroz, do feijão, da carne, da fruta... (Rose, 2018).

Tudo o que eu tenho hoje na minha vida, tudo o que eu consegui conquistar foi através disto daqui. [...] Paguei a faculdade das duas filhas com minhas vendas [...] Eu fui vendo que era melhor do que trabalhar para os outros. Daí eu tive minha filha e com criança pequena para sair para trabalhar é difícil. Daí eu comecei a ir buscando, coloquei a loja e deu certo (Dilma, 2018).

Em alguns casos, o engajamento é justificado como um meio para fazer frente a necessidades materiais que não são da própria comerciante, mas de um membro do grupo doméstico que passa por dificuldades. Maria Cristina trabalha na administração financeira de uma escola estadual. Passou a revender roupas no último ano para complementar a renda e ajudar sua filha de 26 anos que, desempregada, enfrentava dificuldades financeiras e emocionais. Atualmente, a filha a ajuda, indicando o que comprar com base em imagens de redes sociais, coletando encomendas de amigas e vendendo para elas.

Essas comerciantes traduzem, com o orgulho de terem conseguido manter seus familiares, o que Duarte (1986) denomina "ideal de obrigação", que associado aos homens na formulação original é aqui assumido por elas. A atividade é vista como um bom cumprimento de seu papel de provisão de bem-estar material, de que depende sua respeitabilidade. Para essas mulheres, o cuidado com a casa e os filhos permanece crucial, e a comercialização de roupas é entendida como um meio de garantir isso em condiçóes de autonomia. É a forma como conseguem defender seu espaço na criação dos filhos longe da interferência de ex-parceiros. Lobo (1989) já indicava esse sentido de autonomia ligado ao trabalho feminino, mas salientava que náo encontrava reflexo nos códigos sociais que atribuíam às mulheres o dever primordial de cuidado com o lar e a família. 
Como esse dever continua presente, a legitimidade de seu envolvimento depende da possibilidade de conseguirem equilibrar o comércio com uma casa e uma família bem cuidadas. E essa conciliação entre o desejo de autonomia, o "ideal de obrigação" e os deveres de cuidado é possível pelas condiçōes específicas em que se realiza a atividade. $\mathrm{O}$ trabalho por conta própria, flexível e sem determinaçóes externas para as não lojistas teria tradicionalmente atraído as mulheres para essas ocupaçôes (Biggart, 1989). Mas o desejo de conciliar a atividade com deveres domésticos está presente em outros arranjos para o comércio de roupas. Enquanto a venda em casa permite a simultaneidade de atividades, a abertura de um espaço de vendas segregado, mas próximo, é vista como uma proteção do âmbito e das relaçôes familiares e, ao mesmo tempo, relevante para o reconhecimento do papel de vendedora no âmbito das relaçôes de vizinhança. Fátima (2018), que recentemente abriu uma loja no bairro onde mora, justifica sua satisfação com a atividade nesse registro: "Eu trabalho e ainda cuido da minha casa. Fiz minha loja ao lado da minha casa. Assim consigo trabalhar, que é algo que eu gosto de fazer”. Em diálogo com a amiga Valesca, também lojista, ressalta a vantagem de ter uma loja: "Em casa a gente perde muito a liberdade!". Ao que Valesca (2018) completa: "A privacidade, né? Quando a gente tem loja, as pessoas encaram nosso trabalho com mais seriedade". ${ }^{11}$

O elo entre o poder de reprodução familiar e o protagonismo na circulação e troca mercantil de produtos têxteis remete às associações simbólicas entre produção, circulação e guarda de têxteis, de um lado, e reprodução humana, de outro, reveladas por Weiner (1992) para contextos de trocas não capitalistas, com consequências para a posição econômica, política e social das mulheres raramente exploradas. No contexto do circuito de moda popular centrado no Brás, em que as trocas são marcadamente mercantis, o elo é recolocado não por meio do poder dos objetos (inalienáveis) de produzir simbolicamente a descendência, ${ }^{12}$ mas pelo potencial da revenda de roupas de garantir materialmente a reprodução ao mesmo tempo que permite o cumprimento de deveres de cuidado. $\mathrm{O}$ poder, com suas consequências a um só tempo econômicas e sociais, está ligado fundamentalmente ao desempenho da atividade mercantil, mas quando esse fenômeno é cotejado com outros estudos sobre trabalhadores ambulantes, em que a presença feminina é reduzida, resta claro que esse elo é possível pelo comércio de objetos de vestuário, fortemente identificados com as mulheres.

\section{Retorno financeiro}

A identificação da atividade com o potencial de oferecer os meios materiais para o cuidado do grupo domiciliar e, assim, o cumprimento do ideal de obrigação não seria possível se as revendedoras não reconhecessem ganhos materiais na atividade. Eles são outro elemento que confere sentido e assegura a identificação com a revenda. Quando rendimentos são mencionados, o que é mais comum entre sacoleiras e pequenas lojistas, os valores giram em torno de 2 mil a 3 mil reais por mês. ${ }^{13}$ Entre aquelas envolvidas há mais tempo na atividade, há casos em que os ganhos produziram conforto material e permitiram ampliar os negócios, sinal de mobilidade destacado em algumas narrativas. Isabel (2018), que revende roupas do Brás há trinta anos, conta que começou como vendedora de marmitas e salgados, comprou uma loja pequena e, hoje, tem um "magazine" no centro de Jardinópolis (SP). Mesmo com ensino superior, preferiu dedicar-se ao comércio (Isabel, 2018).

A necessidade aparece em alguns discursos como motivador do início da atividade, mas, quando desaparece, o desejo de ampliar os ganhos é apontado para justificar a manutenção na atividade. Foram cinco as mulheres entrevistadas que indicaram que, em condiçôes de desemprego, decidiram vender roupas. Entretanto, essas mulheres não pensam em abandonar a atividade, quer a assumindo como principal ocupação, quer a conjugando com outros empregos. O sentimento de realização para elas não se desvincula dos ganhos materiais, e é isso que buscam na atividade, diante de empregos que não oferecem o mesmo. Em uma sociedade que valoriza o acúmulo, o ganho atrelado a uma ocupação é importante fator de reconhecimento. Rafaela (2018) descreve seu envolvimento com a revenda de roupas nessa chave: 
[Comecei a vender] porque eu fiquei desempregada. [...] Daí eu tive uma proposta que eu achei que não valia a pena, pelo que eu já tinha passado, pelo que eu já tinha estudado. [...] A gente tem que dar valor ao nosso trabalho, tem que dar valor ao nosso estudo. Daí eu peguei e falei "não, eu vou trabalhar com vendas". [...] Eu gosto do dinheiro. Eu gosto é de ser professora, mas o gostar tem que vir juntamente com a remuneração.

No conjunto de mulheres, como Rafaela, com passagens em sua trajetória ocupacional com a educação infantil (quatro), seja no magistério, seja em funções administrativas, era comum um sentimento de desalento com a ocupação, conjugado com um desejo de abraçar as vendas como atividade. Assim como Isabel e outras revendedoras com formação superior, a revenda torna-se preferível e, pelo ganho que traz, importante para o modo como se definem, pondo em suspensão a importância da credencial educacional, forte elemento de legitimação de pretensôes identitárias (Dubar, 1991).

Talita (2018), por exemplo, que viaja ao Brás para abastecer a loja do marido, dizia-se cansada de ser professora, área que acha pouco "favorável", e afirmava que queria abrir uma segunda loja:

Essa área de loja eu estou achando mais interessante. Porque, além de trabalhar nesse horário [todos as tardes], [como professora] eu levo muito trabalho para casa.

Ao comentar esse desejo, indicava a qualidade que reconhece no comércio de roupas: a possibilidade de ampliar seus ganhos dispendendo menos esforços. ${ }^{14}$

Essa percepção está assentada em uma concepção do que constitui trabalho na revenda de roupas para aquelas que não dispóem de um ponto comercial. A narrativa de Rafaela (2018) esclarece essa concepção, ao mesmo tempo que exalta o potencial de ganhos com a atividade: "Eu trabalho três, quatro dias por mês e ganho o que um professor ganha. [...] Um professor trabalha 20 horas por semana [...]. Eu estou gostando". O trabalho aparece, então, associado exclusivamente à duração das viagens para São Paulo. Porém, sabemos por entrevistas e pela observação que o trabalho envolve um cauteloso esforço, discutido na próxima sessão, de anúncio das peças, comunicação com clientes e atendimento que se prolonga durante dias. Como esse conjunto de tarefas é feito em meio a laços que Rafaela mantém com os membros de sua comunidade religiosa, com quem comercializa as roupas, é deslocado do domínio do trabalho.

\section{Ideal de autonomia}

Os sentidos de realização e dignidade associados à ocupação são ainda mais evidentes quando a necessidade, seja pelo arranjo familiar, seja pelo desemprego, pode ser afastada. O trabalho por conta própria nem sempre é consequência da exclusão ou da perda de ocupaçóes salariais, chave com que é frequentemente compreendido pela literatura (Abílio, 2014; Malaguti, 2001). Entre as entrevistadas encontramos jovens com formação universitária que preferem a atividade ao emprego formal em sua área de formação, bem como mulheres que abandonaram empregos para se lançar na atividade comercial. Embora suas narrativas considerem, para essa decisão, um interesse em aumentar sua renda, a identificação com a atividade também é mencionada como um fator.

Alessandra (2018) era funcionária pública em Recife (PE) antes de, infeliz com a ocupação, decidir abrir uma loja. Hoje, ela diz, não apenas é mais feliz trabalhando com moda, que é o que sempre gostou, como também tem uma renda maior. Juliana (2018) abandonou um emprego que mantinha há dezessete anos em um hospital e decidiu revender roupas, acessórios e bolsas adquiridas em São Paulo. Reconhece que sua renda aumentou e diz que "ama o que faz". A realização está associada, em sua narrativa, às viagens ao Brás para ver as novidades, às atividades de venda ("Gosto de postar as fotos das peças") e às relaçóes que mantêm com suas clientes, outros sentidos comuns da atividade elaborados a seguir.

O primeiro desses sentidos destacados pela narrativa de Juliana (2018), e aquele que mais desafia o conhecimento acumulado, é o potencial de autonomia reconhecido no trabalho por conta própria. A atividade de vendas é frequentemente valorizada por sua contraposição à experiência de subordinação empregatícia, que é rejeitada. Neida (2018) associa o trabalho por conta própria ao crescimento pessoal: 
Eu trabalhava de empregada [doméstica] assim, né? Então, assim eu trabalho com o que é meu, né? Estou ganhando o meu, estou trabalhando do meu jeito, né? [...] Para mim está me servindo, muito, né? Está me ajudando bastante, né? [...] O de trabalhar com o meu negócio [...], é trabalhar com tuas próprias pernas. Quando você trabalha para os outros, você trabalha com as pernas dos outros, né? Os outros vão crescendo, tu vai atrás deles. E trabalhando por conta, tu caminha com tuas pernas. [...] Se é pra crescer, tu vai crescer. [...] Eu não ganhava nem salário mínimo limpando casa dos outros.

Essa aversão à subordinação empregatícia, ligada a experiências ruins, aparece também na experiência de Larissa (2018) para explicar seu desejo de ter um negócio próprio:

Uma coisa que eu não gosto é que alguém mande em mim. [...] Daí eu pensei 'nunca mais eu quero trabalhar para ninguém'. Porque onde eu trabalhava, a mulher era daquele jeito... Nossa Senhora, eu fui muito humilhada, demais da conta.

Evidentemente, o percurso particular importa para o sentido das experiências. Essa preferência poderia, também, estar relacionada às limitaçôes das oportunidades das mulheres no mercado de trabalho e, como vimos anteriormente, à possibilidade de conjugar a ocupação com as obrigaçóes de cuidado que continuam recaindo majoritariamente sobre as mulheres, como ponderam Abílio (2014) e Biggart (1989). Porém, as trajetórias ocupacionais ou as narrativas das entrevistadas não registram sinais de conformismo biográfico. Essa preferência tampouco depende de um percurso marcado por ocupaçóes prévias degradantes ou trajetórias mais curtas, das jovens. Vanessa (2018) era gerente de uma loja em sua cidade, mas não queria mais trabalhar para os outros. "Determinada e focada", como se considera, decidiu "ser empreendedora" e afirma que seu maior desejo é fazer que clientes se sintam bem dentro de sua loja. Outras entrevistadas preferem a atividade a empregos na área de sua formação em razão de seu gosto pela moda, um sentido explorado adiante.
Se a ascensão da forma salarial como padrão desejado de participação econômica esteve ligada ao declínio do comércio migrante no passado europeu (Fontaine, 1993), o enfraquecimento do ideal do emprego registrado parece explicar sua resistência contemporânea. O salário fixo, regular, é um elemento que permanece valorizado em discursos que ponderam que a flutuação dos rendimentos é um dos desafios da profissão. Entretanto, a ausência de subordinação na produção do próprio ganho é ressaltada em meio a essa ambivalência.

Novamente, parece significativo que o potencial de autonomia esteja ligado à circulação de têxteis. Ainda que desprovida do poder simbólico de representar o parentesco, a união política ou as forças espirituais e ancestrais que a roupa outrora possuiu (Weiner e Schneider, 1989), a troca mercantil de roupas oferece ganhos materiais e autonomia às mulheres, ao mesmo tempo que garante a reprodução familiar. $\mathrm{O}$ poder dessa atividade de produzir uma relativa autonomia para as mulheres não depende de uma identificação com os objetos que são comercializados. Com efeito, algumas entrevistadas reprovam a qualidade ou as propriedades estéticas das roupas, mas destacam o ideal de autonomia associado à atividade. Ainda assim, as mulheres têm no universo têxtil um espaço de legitimação de pretensões identitárias e reconhecimento de competências mercantis.

\section{Identidade de ofício: gosto de vender e gosto pela moda}

Além da autonomia do empreendimento pessoal, o gosto pela venda e pelo bom atendimento a clientes é outro sentido que produz identificação. As demandas e dificuldades do atendimento a clientes são reconhecidas, mas os esforços necessários produzem um sentido de respeito próprio. Fátima (2018) expressa satisfação e um considerável orgulho de ajudar, por meio de sua loja, sua comunidade, ainda que isso lhe importe em dificuldades:

Já trabalho há 23 anos, quatro anos com a loja. Eu falo que, na verdade, eu trabalho desde os meus 11 anos de idade. Porque eu sempre gostei de vender. Eu aprendi a fazer crochê, fazia crochê, 
fazia paninho, vendia, rifava... Eu sempre gostei de lidar com as pessoas, entendeu? [...] Tem aqueles meus clientes que, às vezes, chegam em casa e falam "Fátima, me salva!" [...] Daí eu falo assim "Espera um pouquinho" e eu vou lá, pego a chave, abro a loja. O meu negócio é vender, porque eu quero é ganhar dinheiro! (risos) [...] $\mathrm{O}$ melhor de tudo é que a gente faz o que a gente gosta. É cansativo? É. Meu pé está todo inchado. Meu pé está doendo! Mas é uma coisa gostosa, uma coisa prazerosa.

O gosto pela atividade aparece relacionado também às relaçôes que por meio dela se cultivam. Marilza (2018), embora guia, expressa o prazer que advém das relaçóes cultivadas nas viagens:

Depois enganchei nisso daqui que é uma cachaça! Isso daqui é uma cachaça, a gente começa... pra parar é terrível. Porque a gente faz amizade com os passageiros, $[\ldots]$ torna-se divertido.

As interaçóes que a atividade comercial promove ampliam o escopo da sociabilidade dessas mulheres. Lobo (1989) argumentara que essa sensação era comum e, por vezes, um anseio entre mulheres que trabalhavam fora do domicílio. Aqui, porém, a sociabilidade não corresponde às relaçóes salarial e de camaradagem no ambiente de trabalho, mas sim às relaçôes comerciais que as revendedoras estabelecem com suas consumidoras. A atividade permite, também, cultivar relaçóes de parentesco, vizinhança e amizade nas quais a venda é realizada, ainda que administrar essas relaçōes sem obscurecer o caráter mercantil da troca seja um desafio de que depende o êxito na atividade. Em outras palavras, o gosto pela venda também se relaciona ao seu potencial de atuar como meio de criação, manutenção e definição de relaçóes sociais, ou seja, de realização do que Zelizer (2005, p. 35) denomina "trabalho relacional", ainda que envolva uma difícil definição dos meios de prestação adequados quando essas relaçôes precisam ser enquadradas na chave mercantil.

A valorizaçâo da atividade comercial possui, para algumas entrevistadas, um qualificador. Trata-se do gosto pela moda e o desejo de comercializar, especificamente, essa classe de objetos. Entre as mulheres que oferecem informaçôes sobre a moda e a região, promovendo-a por meio de canais digitais (YouTube, Instagram e Facebook), o desejo de se engajar em uma atividade relacionada com a moda é unânime. Para elas, trata-se de entrar em um mundo da promoção da moda, apenas em um segmento diferente - mais acessível - que promotoras mais célebres. No entanto, a identificação com a moda também está presente e é apontada como o fator determinante para o início da atividade entre lojistas e sacoleiras. Para essas mulheres, tornarem-se mediadoras no circuito de moda popular do Brás é uma forma de se envolver no domínio da moda com recursos limitados.

Esse sentimento é mais expresso entre as mais jovens. Larissa (2018), por exemplo, trabalhava numa loja de roupas e, ao ser demitida, decidiu abrir sua loja porque: "Eu gosto de mexer com roupa. Amo, amo! Daí eu pensei 'vou abrir uma [loja] pra mim". Cursando engenharia, pretende continuar no ramo depois de formada. Paula (2018) expressa o mesmo interesse. Formada em arquitetura e com experiência profissional na área, preferiu abrir um negócio on-line de revenda atacadista de roupas. Desde os tempos de faculdade, percebendo que não gostava muito da área, passou a importar de sites chineses peças que vendia para amigas, vizinhas e colegas. Ela diz que sempre gostou de moda e, sem condiçóes de cursar uma faculdade na área, decidiu revender roupas, primeiro em casa e, depois, por meio de um site que vende no atacado para lojas de outros estados. Cristina (2018) é outra revendedora que, embora com curso superior em administração, afirma preferir o comércio de roupas, atividade que seus pais, proprietários de uma malharia, já realizavam. Para essas e outras entrevistadas, o trabalho lhes permite acessar o universo cultural das tendências, da moda e dos estilos a que aspiram, não menos pela exposiçấo que lhes oferece em suas comunidades. São, afinal, agenciadoras da moda, não apenas em um sentido material como também transmitindo os símbolos estéticos em que se sustenta o consumo de moda popular.

Nesses três casos, a legitimidade que a credencial educacional oferece é menos importante para a reivindicação de uma identidade ocupacional que a forte identificação com as atividades relacionadas ao comércio e com o objeto transacionado. Essa 
identificação sugere uma identidade de ofício, embora em sentido diverso do tradicional, atrelada ao saber-fazer das vendas - atender e mediar a circulação de roupas - e, especificamente, da moda - as preferências, tendências e qualidades dos produtos. Diferentemente das identidades de ofício discutidas na literatura (Dubar, 1991; Zarca, 1988), ${ }^{15}$ é desenvolvida fora de uma carreira ou de uma organização, não é protegida por espaços institucionais que lhe conferem legitimidade e proteção da concorrência (como órgãos de classe, sindicatos ou corporaçóes) e chega a suspender a importância das credenciais educacionais como critério de identificação de saberes e competências, embora seja reconhecida pelos seus atores e por outros a seu redor. Baseada em saberes práticos desenvolvidos por meio da experiência, essa identidade é mais parecida com a dos antigos ofícios que desapareceriam que com aquela que, de acordo com Dubar (1991), teria emergido em conexão à autonomia operatória nas grandes empresas e corresponderia ao domínio de capacidades analíticas e intelectualizadas e saberes lógicos sobre procedimentos.

Essa identidade depende do reconhecimento do êxito na atividade, que atua como uma confirmação externa de que possuem esse saber-fazer particular do ofício. Por isso, tal identidade pode ser apreendida por contraste nos casos das mulheres que abandonaram a atividade por não possuírem as habilidades necessárias. Nos casos em que, postas à prova, náo conseguem sustentar a identidade para si ou para outros em razáo do que entendem como fracassos, elas a rejeitam. É o que permitem antever os discursos daquelas que tiveram de abandoná-la, mas que são ainda encontradas, em outras funções, no circuito. Nesses casos, são explícitos o desejo reprimido e a frustração com a impossibilidade de exercer a oportunidade, que pode ser de duas diferentes ordens: problemas financeiros que comprometeram o necessário capital de giro ou falta de habilidade.

As duas "laranjas", pagas para transportar para Sáo Paulo mercadorias vindas do Paraguai que recebem em suas cidades, revelam essa frustração ao mencionar o abandono de atividade de vendas. Margarida (2018) diz que, após muitos calotes vendendo lingerie e cosméticos, desistiu da profissão e náo pensa em revender roupas. Maria (2018), por sua vez, indica o desejo de retornar às vendas, mas com outro modelo de negócio. Tendo se tornado sacoleira para complementar a renda que obtinha e manter seus filhos após a separação, perdeu uma grande quantia em um negócio com sua mãe. Para solucionar problemas financeiros, acordou comprar 10 mil reais em mercadorias que sua máe revenderia em seu estado. Entretanto, a mãe jamais lhe transferiu a quantia que recebeu. Ao contrário de outras mulheres que enfatizam sua autonomia e livre-arbítrio, Maria lamenta a falta de apoio externo. Ela se arrepende de náo haver permanecido com as vendas que, acredita, teriam garantido retornos maiores que os empregos que manteve. Revela o desejo de retomar a atividade, mas, para evitar os problemas de pagamento, pretende vender apenas para lojistas em seu estado natal. Dificuldades em receber de conhecidos, que constituem uma parcela significativa dos clientes são também mencionadas por ex-sacoleiras que, hoje, frequentam o Brás em viagens para consumo próprio.

\section{Ideal de circulaçáo na cidade grande e suas oportunidades de socializaçáo}

Há, ainda, uma valorizaçẫo da bravura e autonomia necessárias para se lançar em longas viagens à maior cidade do país. A representação em torno da atividade não se separa, nas narrativas, das representaçóes em torno da mobilidade frequente e do local onde são feitas as compras. A coragem como uma qualidade que a atividade revela é reconhecida por Maria que, atualmente "laranja", começou a vir ao Brás como sacoleira. Mas a coragem também aparece como resultado da atividade, como no caso de Juliana, que menciona que se tornou mais corajosa, estado que contrapóe à imobilidade prévia. Margarida (2018) também contrapóe seu envolvimento ao momento anterior em que "só ficava em casa; só via novela".

A atividade justifica uma existência produtiva não apenas fora de casa e da família como também de suas cidades, um aspecto valorizado, ainda que de modo ambivalente. Para essas mulheres, oriundas de cidades de pequeno e médio porte, São Paulo figura - ou o fragmento em que circulam - como um local desordenado e até perigoso, mas fascinante. As viagens, por sua vez, são consideradas cansativas, mas 
permitem romper a rotina de obrigações domésticas e profissionais. Como fazem suas compras com dinheiro em espécie, precisam ser cautelosas no Brás. Mesmo assim, utilizam palavras como "divertimento", "fascinante" e até "desestressa" para se referir às suas viagens a São Paulo.

O fascínio exercício pela cidade é bem expresso por Margarida (2018) que, como outras, diz que sente falta de São Paulo após períodos mais longos e dos encontros que a cidade possibilita:

Cada pessoa é um livro, todo dia você conhece uma história diferente, uma pessoa diferente, de todos os lugares do Brasil, entâo você acaba esbarrando, trocando ideia, eu acho interessante.

A mobilidade da ocupação faculta a suas protagonistas o acesso a um espaço público ampliado, não apenas das relaçóes locais em suas cidades de origem como também da metrópole.

\section{Saber comprar, saber vender, saber receber: as competências para fazer "a modinha" e ganhar a vida}

Entre as entrevistadas que dominam as competências necessárias, a atividade é inserida nas suas construções como garantidora de conforto material, das obrigaçóes para com seu grupo doméstico, de autonomia e expressão de suas personalidades ligadas à venda, ao atendimento, à moda e ao constante movimento. Esses casos apontam para um aspecto importante nas construções simbólicas em torno da atividade no interior de experiências biográficas. A identificação com a atividade depende da capacidade de dominar as competências que lhes permitem extrair retornos. A distribuição dessas competências é desigual, o que explica o destino diferencial e a identificação também variável com a atividade. Há situações de pesquisa muito significativas a esse respeito. A guia Marilza (2018), quando interrogada por que não aproveita as viagens para adquirir mercadorias para a venda, explicita essa desidentificação ao afirmar que "Não dou jeito para isso náo. Sou ruim de vendas", antes de, visivelmente incomodada, interromper abruptamente nosso diálogo. Resta compreender, portanto, quais são e como se constroem essas competências.

Os agentes econômicos não se constroem no vazio nem os objetos que eles comercializam. Os agenciamentos necessários para promover os fluxos de um circuito dependem de um conjunto de competências adquiridas por meio da experiência no circuito e distribuídas desigualmente entre agentes. Essas competências não se limitam a uma genérica capacidade de cálculo inscrita em uma racionalidade utilitarista. Os contextos sociais específicos em que as etapas da atividade se desenvolvem requerem distintas racionalidades práticas (Weber, 2002). Também não se restringem à habilidade social de produzir a cooperação necessária para a ação coordenada de que depende a troca mercantil (Fligstein, 2007), embora essa seja uma habilidade necessária para agir sobre o circuito e seus jogos.

Há três competências básicas de que depende o êxito na atividade: saber comprar, saber vender e saber receber. Saber comprar pressupóe, em primeiro lugar, deter a competência de distribuir os bens disponíveis em um mercado de acordo com a sua qualidade, atribuindo-lhes diferentes valores (Callon e Law, 2005). Na Feira da Madrugada e no Brás em geral, essa competência é auxiliada pela operação de dispositivos que distribuem os bens, segundo sua qualidade, no espaço de trocas. Embora seja conhecido pelo baixo custo e pelas oportunidades para revendedores, no Brás há roupas de diferentes padróes de qualidade e faixas de preço. Como em outros mercados de rua (Geertz, 1978; Weber, 2002), os sinais de qualidade permanecem opacos para leigos, e essa opacidade constitui uma oportunidade de lucro e embuste para vendedores na Feira da Madrugada. Logo, a capacidade de decifrá-los é imperiosa para quem depende da revenda das roupas. $\mathrm{O}$ próprio espaço é organizado de um modo que indica, para muitos dos seus frequentadores, as diferenças de qualidade. Nas ruas, sobre lonas ou em barracas são comercializadas peças que são consideradas de pior qualidade, produzida localmente ou importada. Muitas revendedoras associam-nas a tecidos de baixa qualidade e modelos pouco duráveis. Galerias são locais onde é possível encontrar roupas de qualidade e preço intermediário, e alguns shoppings e lojas 
atacadistas, com espaços mais organizados e modernos, comercializam roupas de melhor qualidade. Assim, os segmentos espaciais desse mercado estratificam bens e agentes, atuando como um dispositivo coletivo de cálculo (Callon e Muniesa, 2003).

Esses elementos integram o conhecimento local exigido dos agentes (Geertz, 1978). Embora auxiliem no saber comprar, não solucionam a dificuldade em determinar quais peças adquirir. A moda está intimamente ligada à mudança constante, além de englobar uma diversidade de estilos que se relacionam a pretensões de expressão individual ou de grupos. A incerteza, portanto, lhe é constitutiva. Nem toda peça que emerge pronta de uma oficina de costura torna-se moda ou vai ser desejada (Godart, 2012). Para mitigar a incerteza, há várias instituições que facilitam o processo de seleção (Kawamura, 2005). Os agentes da moda valem-se tradicionalmente de feiras, publicaçóes, meios de comunicação digitais, no geral, e redes virtuais, em particular, que têm se tornado cada vez mais importantes na difusão de imagens que geram demanda.

Para saber o que será vendido, lojistas e sacoleiras têm diante de si os mesmos desafios e instrumentos para sua superação. Muitas afirmam ir ao Brás em busca do que denominam "modinha": roupas básicas, com demanda expressiva de giro muito rápido (menor de um mês, dizem), sazonais e particularmente associadas a celebridades. A despeito de seu diminutivo, que em termos semânticos indica sua inferioridade em relação à moda das célebres marcas internacionais, a clássica tensão entre imitação e distinção já descrita por Simmel (1957) e Blumer (1969) está também aqui presente. A imitação é baseada na adaptação de imagens de celebridades para produzir modelos que já nascem consagrados. Christian (2018), um produtor de roupas local descreve esse processo:

Lembra aquela novela com a Jeiza, que era a Paolla Oliveira no ano passado [2017] ${ }^{16}$ ? Eu levava um vestido de malha canelada que vendeu muito [...]. Se está na novela, se alguém famoso está usando e sabe como é né? O povo quer ser igual, então quem chegou com isso estourou, vendeu muito, tipo mil peças por dia. Até mais, 5 mil peças por dia.
É retroalimentada por promotoras virtuais da moda popular que exibem essas peças e indicam onde as comprar, mas também por programas televisivos dedicados à vida de celebridades. Muitas revendedoras alegam acompanhar as telenovelas para saber quais peças serão desejadas. Juliana (2018), por exemplo, menciona que não costumava seguir a moda, mas que suas clientes pedem o que é da moda, o que veem em mídias eletrônicas.

O desafio de saber comprar não se limita a identificar a "modinha" do momento. Mesmo sabendo quais artigos comprar, saber o quanto investir em tais itens também é desafiador. Voltadas a um consumo frequente, como toda fast fashion, peças de "modinha" são muito efêmeras, as revendedoras indicam. Se essas peças não são vendidas logo após a compra, as chances de venda diminuem muito. Esmeralda (2018) conta:

Você não pode apostar muito na 'modinha', porque toda semana ela muda. Eu comprei um macacão aberto que aquela menina da novela das 8 estava usando. Comprei dois. Um já encalhou, porque já entrou o frio. Ninguém vai usar macacão aberto.

Como outras, alega que não se deve comprar muitas peças.

O limite da "modinha" é, também, o da imitação no jogo social da moda. Saber comprar, muitas revendedoras afirmam, é saber o que querem suas clientes que também desejam diferenciar-se por meio de suas roupas. O desafio é combinar os movimentos de pertencimento coletivo e diferenciação que caracterizam a moda (Crane, 2011). Haddad e Castro (2019) descrevem, entre consumidoras de baixa renda, o rechaço a uma moda que consideram padronizada e que as tornaria imitadoras, mas também os esforços para conjugar essa moda com estilos pessoais, por meio de apropriação seletiva, combinação de diferentes elementos e escolha de objetos que integram a moda. O desafio para as vendedoras corresponde a considerar essas atitudes de consumo. Para quem vende, a moda age como um símbolo do consagrado e reduz a incerteza, mas é necessário considerar os estilos percebidos das clientes no universo da roupa para bem exercer sua atividade. 
Em termos práticos, isso significa comprar peças que sejam do agrado das clientes e, ao mesmo tempo, únicas e exclusivas, sempre novas, em um universo massificado. É para isso que modificam fornecedores, sempre procuram novidades no Brás e algumas alternam suas visitas à Feira da Madrugada com outros polos, como Goiânia. Essa é uma explicação que oferecem para a frequência de suas viagens e a recusa em comprar remotamente a roupa, sem a ver.

O desafio de singularizar as peças para permitir que sirvam à expressão individual de suas clientes é particularmente acentuado entre aquelas que vendem em cidades pequenas. Nesses casos, logo aprendem que não podem comprar duas peças iguais e precisam frequentar polos de distribuição e lojas distintas dos concorrentes. Como explica Andreia (2018):

Não compro dez peças disso, vinte daquilo. Não, são únicas. Por isso que eu canso tanto: eu ando de loja em loja e compro duas ou três peças de cada loja. [...] É porque eu moro em cidade pequena. Tem muitas lojas e a maioria das lojas vem pra cá para comprar. Se tu levar o que todo mundo leva, ninguém vai na sua loja comprar.

Um atributo fundamental desse saber é comprar o que as clientes vestem e não o que as vendedoras gostam. Para tanto, é importante conhecer os desejos e gostos da clientela. Mesmo aquelas que têm lojas maiores, ressaltam que é necessário conhecer o público, atentar para o que estão usando e pedindo. Mesmo afirmando que se guia pela moda, procurada pelas clientes, Juliana (2018) afirma que precisa considerar o gosto de suas clientes. Para promover as vendas, publica fotos das peças nas redes sociais e em um grupo de mensagens digitais que mantém com clientes. Val Meireles (2018), que além de revender, possui um popular canal no YouTube com dicas sobre o Brás e sobre o trabalho de revenda de roupas, também aconselha a comprar tendo em mente clientes conhecidas em potencial (Como vendo roupas ??. Vídeo no Youtube, publicado em 27/03/2018. Disponível em: https:// www.youtube.com/watch?v=MLpQjaNrvro). Os meios de comunicação eletrônica ajudam a manter uma proximidade permanente com clientes e permitem que enviem encomendas, que aceitam com reticências pelos riscos de desistência posterior. Monitorar a concorrência também é mencionado como um método para compreender a demanda. Talita (2018) conta que acompanha a conta de Instagram de uma popular loja de sua cidade para decidir o que comprar. Vemos aqui a dinâmica de observação recíproca que White (1981) reconhecera, não em um mercado de produtores nem para encontrar um nicho, mas para identificar tendências e compreender a demanda.

Servir ao gosto e à demanda dos clientes é, às vezes, descrito como uma necessidade que exige um esforço de suspensão do próprio juízo e gosto. A "modinha”, por exemplo, nem sempre é admirada. Ela é vista como roupa "de piriguete" (Paula, 2018) de baixa qualidade e muito barata. A pressão pelo baixo preço conduz algumas revendedoras, sobretudo as veteranas, a comercializar peças cuja qualidade questionam. Isabel (2018), há três décadas na atividade, reclama, por exemplo, da queda da qualidade das roupas. Antigamente, comprava no Bom Retiro (bairro de São Paulo), onde as roupas têm maior qualidade, mas hoje as pessoas querem roupas baratas. Isabel (2018) lamenta:

Isso faz com que opte por produtos mais simples, sobretudo os de importação chinesa. Não gosto de trabalhar com as roupas que vêm de fora, mas eu sou obrigada. [...] Não tem manequim adequado, a qualidade, o tecido, não é como a que tem fabricação no Brasil, mas o preço não se compara, o que vem de lá é muito barato, com os impostos que eles pagam aqui não tem como.

Não há, portanto, uma necessária identificação com os bens que são transacionados, embora reforce a identidade de ofício nos casos em que está presente.

O cultivo permanente das relaçóes de clientela e os canais utilizados para tanto são também essenciais para vender, uma segunda competência exigida. Vender exige complementar o esforço de singularizaçáo iniciado na compra de peças diferentes, mobilizando, para tanto, laços na cidade de origem. Frequentemente vende-se para uma clientela com quem se mantém relaçóes de proximidade: vizinhança, amizade e parentesco. No caso daquelas que têm no comércio sua atividade secundária, é comum utilizar relações 
profissionais também. A preferência pelos negócios em um âmbito de proximidade mitiga riscos. Essas relaçóes são cruciais para todo tipo de arranjo de vendas: para quem não tem um ponto comercial fixo, para comerciantes de rua, que assim garantem um fluxo contínuo de clientes, e até mesmo para lojistas maiores, como reconhece Isabel, que recebe encomendas de clientes por WhatsApp e está sempre atenta ao que suas clientes lhe pedem na loja.

Esses laços são mobilizados para escolher peças e vendê-las, domesticando as tendências globais da moda popular e singularizando-as para o que suas consumidoras podem reconhecer como seu estilo. Assim, muitas revendedoras utilizam grupos de mensagens digitais para receber fotos de modelos desejados e enviar fotos de modelos que encontram em São Paulo. Maria Cristina (2018) afirma que, às vezes, já sai de uma loja no Brás com várias peças vendidas. Aliás, mesmo com a preferência por vender em círculos sociais próximos, a internet é fundamental nas estratégias de venda. Quase todas as revendedoras utilizam algum canal digital, como Facebook, Instagram e WhatsApp, onde postam fotos dos modelos adquiridos.

Como vimos ao discutir as causas de abandono da atividade, uma terceira competência exigida é saber receber. Garantir o pagamento é um desafio considerável. Trata-se do principal drama para algumas revendedoras, como confidenciou Fábio (2018), guia e verdadeiro conselheiro. Se elas não souberem cobrar, podem ter prejuízos de milhares de reais. Para isso, as mesmas relaçóes de proximidade que podem ajudar também atrapalham. Afinal, é mais comum vender fiado ou em parcelas sem juros entre conhecidos. É frequente, também, que consumidoras, com quem mantêm relaçóes íntimas, adiem ou deixem de pagar. Essas liberalidades podem ser fatais à revendedora, pois comprometem o capital de que necessita para novas compras. Fábio (2018) comenta que a representação do Brás como uma área "em que tudo é de graça" reforça a dificuldade de receber, pois parentes, vizinhos e amigos frequentemente pensam que, se ficarem com uma peça sem pagar à revendedora, não haverá prejuízo considerável. Associada a essa competência está a capacidade de fazer frente aos seus custos de vida e de seu grupo doméstico com um fluxo monetário que é variável.

O trabalho relacional realizado pelas revendedoras é duplo. Por um lado, a troca mercantil anima laços locais, permitindo às revendedoras investir nessas relaçôes. Por outro, é também necessário negociar os meios apropriados de troca em diferentes cenas e relações de que participam essas agentes (Weber, 2002; Zelizer, 2005). Ao contrário do que sugeriram Weiner e Schneider (1989), mesmo em um contexto de trocas mercantis, a roupa ainda pode ser entendida como uma prestação que atende obrigaçóes sociais e alimenta afetos, se ocorrem entre conhecidos que mantêm outras relaçôes. O desafio, portanto, é evitar que a troca seja subsumida a essas relaçóes e convertida em presente, garantindo um ganho pecuniário e a reprodução dessas relaçóes.

No conjunto de estratégias desenvolvidas para permitir a cobrança, destacam-se a constituição de um ponto fixo de venda e a utilização de meios de pagamento eletrônico. ${ }^{17}$ A loja elimina o perigo de contaminação entre relações pessoais e comerciais que promove confusóes entre a venda e a dádiva, ao mesmo tempo que, estando localizada na região de residência de vendedora e compradores, permite aproveitar-se dos laços de proximidade. Os novos meios de pagamento, por sua vez, transferem o custo da cobrança da dívida e garantem o fluxo de caixa das vendedoras.

Esse conjunto de competências de saber comprar, vender e receber, de que depende o êxito e conforme as quais varia a identificação com a atividade, é produto de experiências pessoais. Cada mulher torna-se uma agenciadora da moda popular após acertos e erros. Erros, aliás, são comuns, sobretudo no início da atividade. Mas há alguns fatores de suporte que as ajudam a adquirir as habilidades e reduzir incertezas. Como visto, os meios de comunicação digitais que as permitem conhecer as tendências e modelos em voga, comunicar-se com clientes, recolher demandas e ofertar produtos são importantes instrumentos de apoio. A manutenção de boas relações com guias ou outras vendedoras é um recurso valioso para adquirir conhecimento do território de compras, suas oportunidades e riscos. 
A realização da atividade com cônjuges e filhos, relatada por seis entrevistadas, permite combinar habilidades específicas. ${ }^{18} \mathrm{Na}$ maior parte desses casos, o apoio vem de filhas que lhes ajudam a escolher o que comprar, utilizando para isso seu domínio de instrumentos digitais de comunicação e dos códigos estéticos da moda que neles circulam. Elas também ajudam nas vendas, anunciando peças por meio dos mesmos instrumentos e mobilizando suas redes de contato. Há ainda um caso em que um filho ajuda na administração da loja, auxiliando a vendedora com as contas. Um último fator de suporte é a existência de parentes que já possuíam comércio de roupas e, assim, ajudam a compreender o negócio, a saber o que e onde comprar. Um quarto das entrevistadas (sete) possui familiares que já compravam no Brás e/ou comercializam roupas. A tradição familiar e a presença de redes de parentesco que dão sustentação à atividade são elementos há muito característicos do comércio itinerante (Fontaine, 1993).

Aptidóes herdadas e adquiridas por meio de longas trajetórias comerciais individuais e familiares certamente auxiliam oferecendo aprendizado sobre a atividade e conhecimento local. Em especial, as relações de parentesco permitem transmitir habilidades comerciais gerais, como atender, receber, precificar e manter contas da atividade. Também oferecem contatos e informaçóes sobre fornecedores. Porém, trata-se de uma vantagem limitada pela diversidade de formas de negócio e de roupas comercializadas, bem como pelas mudanças nas formas de produção e consumo de moda nas últimas décadas, expressas sobretudo por revendedoras de maior idade. Assim como a identidade dessas revendedoras não é preestabelecida pela sua trajetória prévia ou posição objetiva no momento de sua entrada na atividade, como visto, as habilidades e o êxito na atividade também não o são.

As aptidóes que as relações familiares e a trajetória oferecem são, como afirma Dubar (1991), recursos subjetivos que podem ou não ser mobilizados. Como outros atores sociais, revendedoras podem recorrer a outros sistemas de referência (Lahire, 2011), adotar estratégias diferentes das herdadas ou desenvolvidas em seu passado, promover novas relaçôes ou procurar modificar o modo como atuam. Os códigos da atividade e dos produtos mudam também como fruto do trabalho e da criatividade das comerciantes. Esse é o caso de Cristina (2018), filha de proprietários de uma malharia, que passou a revender roupas adquiridas na Feira da Madrugada, sobre as quais pouco sabia, para aumentar os negócios dos pais em meses mais quentes, tradicionalmente de baixo movimento na loja da família.

\section{Consideraçóes finais}

Este artigo procurou descrever um circuito de distribuição de moda popular, suas agentes e as intermediaçôes necessárias para sua atividade, apurar o sentido da atividade diante de diferentes trajetórias ocupacionais e arranjos familiares e verificar as definiçóes de moda e as competências que determinam a sua fortuna (saber comprar, saber vender e saber receber). A presença de um circuito de distribuição de roupas centrado no Brás comprova a existência de circuitos paralelos nos diferentes segmentos de moda no mundo contemporâneo, dotados de relativa autonomia frente aos polos tradicionais, ainda que se alimentem de formas simbólicas de circulação internacional como modelos e marcas (Breward e Gilbert, 2006).

Esse circuito é dependente da itinerância de um conjunto de agentes, de característica fortemente feminina. Mesmo com o progresso de meios de comunicação e transporte, essas mulheres fazem mover a roupa do Brás para o restante do Brasil. Operam, desse modo, uma intermediação entre o mundo local e o da grande cidade, a impessoalidade do mercado no Brás e as relaçóes de proximidade, que mobilizam para vender em suas cidades.

Ao fazer isso, engajam-se em uma atividade que, para a maioria delas, provê um sentido de dignidade e realização. Indiquei que nas construçôes discursivas que fazem de si, a revenda de roupas aparece como uma atividade crucial para garantir bem-estar material, honrar obrigaçôes com seu grupo doméstico, oferecer acesso a um universo de sociabilidade ampliado, exercício de habilidades e autonomia, vinculada a uma identidade de ofício. Essa identificação depende, porém, do acesso diferencial a um conjunto de competências que as torna agentes econômicos e que 
constroem por meio de sua experiência na atividade: conhecer a moda e as preferências das clientes para saber comprar, atender bem, saber vender e receber, mesmo comercializando para pessoas com quem mantêm relações íntimas com diferentes formas de troca.

Afirmar que, ao comercializar roupas que adquirem na Feira da Madrugada, promovendo a circulação dessa moda popular pelo país, as mulheres tecem uma identidade que lhes garante um sentido de dignidade, remete a achados sobre a circulação de têxteis e identidades ocupacionais válidos para contextos muito diferentes, desafiando-os ao mesmo tempo. Weiner (1989) destacara que, em sociedades não mercantis, por meio da produção e troca de tecidos, as mulheres nivelaram a riqueza dos homens. Por outro lado, a contribuição das mulheres à riqueza têxtil seria enfraquecida pelo capitalismo (Weiner e Schneider, 1989). O estudo do circuito de moda popular centrado na Feira da Madrugada revela um papel mais circunscrito para as trocas de roupas na vida das revendedoras e suas sociedades, desprovido de sentidos espirituais e políticos mais amplos. Ainda assim, sugere que a atividade produz recursos materiais e simbólicos e alimenta relaçóes.

A ocupação foi já pensada como um importante fator de construção identitária (Dubar, 1991), mas no interior de relaçóes salariais e em relação a projetos de carreira. A concorrência no mercado de trabalho tenderia a substituir identidades de ofício calcadas em saberes-fazeres, mas aqui vemos o surgimento de uma identidade dessa natureza, afirmada em detrimento de projetos de carreira salarial em situação de emprego formal ou credenciais acadêmicas.

O sentido de dignidade que as revendedoras derivam da atividade indica mudanças significativas nos padróes normativos de ocupaçóes e trajetórias. Em primeiro lugar, a concentração das mulheres na atividade parece desafiar condiçóes estruturais que as desprivilegiam e condenam ao mundo doméstico, mas a associação simbólica da moda com o mundo feminino permite compreender a legitimidade de sua presença. Em segundo lugar, o sentido de realização associado ao trabalho autônomo indica um deslocamento semântico da referência normativa que tinha a ocupação mais desejada no emprego formal.
Considerando as consequências dessas transformações para a sociedade brasileira, é oportuno continuar na tentativa de compreendê-las por meio de outras análises empíricas.

\section{AGRADECIMENTOS}

A pesquisa e análise em que se baseiam este artigo contou com o apoio financeiro da Fundação de Amparo à Pesquisa do Estado de São Paulo (Fapesp), por meio da bolsa pós-doutoral (processo n. 2014/13285-6). Agradeço a Mariel Deak Serapião pela colaboração com o conjunto de entrevistas, bem como a Eny Vereta Nahoum, Talita Vaquero Capella, Tarsila Mercer de Souza e participantes do Simpósio Trabalho e Economia: Intersecçôes Socioantropológicas, realizado no Instituto de Filosofia e Ciências Sociais da Universidade Federal do Rio de Janeiro (UFRJ), em março de 2019, por comentários e sugestôes. Este artigo muito se beneficiou das sugestóes recebidas de três pareceristas anônimos, a quem também registro dívida de gratidão.

\section{Notas}

1 Sempre que o coletivo referido for empiricamente composto majoritariamente de mulheres, adoto o gênero feminino do termo.

2 Essa estratégia permitiu reduzir desconfianças relativas ao discutir as atividades e a moda do Brás que advinham da diferença de gênero, já que a maior parte dos motoristas, como o autor, são homens. A colaboraçáo de uma assistente de pesquisa, Mariel Serapião Deak, em campo, realizando algumas entrevistas, foi igualmente fundamental para estabelecer relaçōes e lograr achados singulares.

3 Mantiveram-se todos os nomes das entrevistadas, exceto os das duas "laranjas", que transportam bens de origem paraguaia sem controle aduaneiro. Por se tratar de uma atividade reconhecidamente ilegal, foram atribuídos nomes fictícios a essas pessoas. Todas e todos os participantes autorizaram a divulgaçáo de seus depoimentos nas entrevistas para fins acadêmicos.

4 Outras pesquisas oferecem aproximações a outras dimensôes e fragmentos, como os mercados (no plural) e segmentos que compóem a Feira da Madrugada em meio a disputas pelo espaço (Vereta-Nahoum, 2019), 
a produção de vestimentas (Freitas, 2013) e, sob forte inspiração dos estudos de cultura material, os sentidos culturais e sociais do consumo de roupas que circulam nesse circuito por grupos de baixa renda, fundamentais para compreender as formas simbólicas da estética popular que conformam o que é moda e, portanto, o que é procurado pelas revendedoras (Haddad e Castro, 2019).

5 Outras instigantes análises a respeito desse circuito sob a lente das mobilidades focaram a migração dos produtores, suas trajetórias e a importância dos fluxos e redes para as atividades produtivas e seus particulares arranjos (Freitas, 2013) ou os laços entre importadores e comercializadores de bens (Silva, 2014).

6 Esse termo genérico designa, mais que um segmento da indústria de vestuário, uma realidade extremamente diversificada, que engloba tipos diferentes de produto, desde a roupa que é vendida na rua até aquela comercializada em lojas de redes globais (elas próprias segmentadas, como Zara, H\&M, C\&A, Mango, entre outras), passando por certo pela roupa encontrada nas lojas dos centros distribuidores paulistas. Em seu aspecto mais geral, a fast fashion é produto da conjunçấo de novas técnicas e arranjos de produção e distribuição com uma nova cultura da moda atrelada à expressão temporária e cambiante (Reinach, 2005). Essa moda foi inicialmente desenvolvida por marcas tendo como alvo jovens adultas interessadas em adquirir com grande frequência roupas relativamente baratas e de giro muito rápido, adaptadas de tendências observadas nas semanas de moda dos principais centros, fartamente disponíveis para consumo por meios digitais. Sua característica central, presente no circuito do Brás, é a habilidade de produtores e comerciantes de identificar rapidamente preferências de consumidores por desenhos populares, testando o mercado semanalmente, com pequenas quantidades de peças produzidas em prazos curtos, às vezes inferiores a um dia. Aquelas que geram demanda são reproduzidas, enquanto isso durar (Doeringer e Crean, 2006). Trata-se de uma moda que se inspira em modelos e tendências da moda pronta para vestir (prêt-à-porter) e, por vezes, a copia, adaptando materiais, cores e formas para um público interessado em roupas de mais baixo custo. Assim, abole custos de desenvolvimento de tendências, modelos e propaganda. Ainda que assim seja, não deixam de ser uma fonte de inovaçáo de produtos. Em geral, a capacidade de empresas de produzir essa moda está ligada a economias de escala e escopo que garantem tempos de produção à comercialização muito curtos: o acesso a tecidos, profissionais de modelagem e redes de distribuição. Ainda que pulverizadas entre vendedores (importadores) de tecidos, oficinas de costura e locais de venda, essas capacidades articulam-se em rede no
Brás. A vida de uma peça de fast fashion no mercado é curta, durando semanas ou meses e adaptando-se à cultura da moda instantânea. Esse sistema de produção, distribuição e comercialização de roupas é analisado em detalhes por Reinach (2005) e Doeringer e Crean (2006).

7 A importância das novelas e de suas atrizes como grandes difusoras de tendências e símbolos da moda entre grupos de baixa renda foi já observado por Haddad e Castro (2019).

8 Há ao menos dezesseis youtubers que produzem regularmente vídeos mostrando as tendências, o preço das peças e onde as encontrar. Sempre com um forte apelo feminino, quer nos temas cobertos pelos vídeos e fotos, quer nas formas de linguagem visual e verbal adotadas para estabelecer uma relação com um público feminino, essas promotoras povoam a rede global de computadores para mostrar para potenciais compradoras peças à venda no Brás e tendências da estaçáo.

9 Para uma análise dessas disputas, ver Vereta-Nahoum (2019).

10 Se, por um lado, há grande esforço analítico para compreender a flexibilização e desregulamentaçáo do trabalho formal, plasmando a experiência social brasileira na trajetória de mudanças estruturais dos países de capitalismo avançado e deles emprestando categorias interpretativas, por outro lado, existe uma escassez de estudos sobre regulação e formalização do trabalho informal promovidas pela criaçáo da figura jurídica do microempreendedor individual (MEI). Seria interessante observar qual taxa e condicionantes de adesão à figura entre comerciantes informais e quais os efeitos sobre a sua situação. Essas são, porém, questões que permanecem inexploradas.

11 O fato de a atividade exigir longos deslocamentos que se traduzem em períodos de ausência da casa cria o desafio de desenvolver arranjos com parentes e vizinhos para o cuidado de filhos. Como as viagens geralmente têm início no período noturno, duram um dia e são realizadas em frequência não superior a quinzenal, é de se supor que esses arranjos não exijam sacrifícios mais significativos do que os exigidos das mulheres que trabalham fora de casa diariamente. Entretanto, como metade das entrevistadas tinha filhos maiores de idade (catorze), alguns dos quais trabalham com elas em suas lojas, um terço não tinha filhos (nove) e apenas cinco tinham filhos menores, não foi possível conhecer esses arranjos senão anedoticamente. É provável que isso seja decorrência do fato de que dois terços das entrevistadas tinham mais de 40 anos (dezenove) e mais de um terço (dez) tinha mais de 50 anos. Nada sugere, porém, que essa distribuição etária seja representativa do universo 
das revendedoras que adquirem roupas na Feira da Madrugada.

12 O caráter ritual e os inúmeros interditos associados à circulação de tecidos que acentuavam as associaçóes simbólicas dos objetos com fontes espirituais e ancestrais estão, evidentemente, ausentes aqui.

13 No quarto trimestre de 2019, esse valor superava o rendimento médio das pessoas ocupadas como trabalhadores por conta própria ( $\mathrm{R} \$ 1734)$ e era equivalente ou maior ao rendimento médio de todos os trabalhos pelas pessoas ocupadas (R\$2 361), de acordo com dados da Pesquisa Nacional por Amostra de Domicilios Continua (PNAD Contínua), realizada pelo do Instituto Brasileiro de Geografia e Estatística (IBGE, 2019b).

14 É interessante contrapor esses casos com o da professora que é revendedora de cosméticos, descrita por Abílio (2014), que se definia (apenas) como professora, não se reconhecendo como vendedora nem mesmo a atividade de venda como um trabalho. A situação é, de todo, diferente aqui. As entrevistadas consideramse vendedoras, sabem quanto a atividade lhes rende e reconhecem que é isso que as move.

15 Refiro-me ao que os autores denominam identité de métier.

16 Christian refere-se à telenovela $A$ força do querer, produzida e exibida pela Rede Globo, de 3 de abril a 21 de outubro de 2017.

17 O crédito por meio dos cartóes também é considerado por Haddad e Castro (2019) como importante meio de promoçáo do consumo entre grupos de baixa renda.

18 Como argumenta Weber (2002), estratégias, cálculos ou mesmo raciocínios nativos que os subjazem não são sempre explícitos ou mesmo conscientes. As habilidades necessárias para a revenda de roupas e estratégias mobilizadas nem sempre apareciam no curso regular das entrevistas. Figuraram, em alguns casos, como parte de narrativas sobre dificuldades ou arranjos empregados para a atividade. Por isso, parecem dever menos a uma determinaçáo anterior à atividade do que à experiência de socialização nela.

\section{BIBLIOGRAFIA}

ABÍLIO, Ludmila Costhek. (2014), Sem maquiagem: $o$ trabalho de um milhão de revendedoras de cosméticos. São Paulo, Boitempo.

ARANHA, Ana. (2017), "Under cover of darkness: inside São Paulo's vast illegal Feirinha night market". The Guardian, 28 nov.
ARAÚJO, Angela M. Carneiro. (2012), "Informalidade e relaçooes de gênero”, in I. Georges \& M. Leite (org.), Novas configuraçôes do trabalho e economia solidária, São Paulo, Annablume, pp. 135-172.

BIGGART, Nicole W. (1989), Charismatic capitalism: direct selling organizations in America. Chicago, University of Chicago Press.

BLUMER, Herbert. (1969), "Fashion: from class differentiation to collective selection". The Sociological Quarterly, 10 (3): 275-291.

BREWARD, Christopher \& GILBERT, David (org.). (2006), Fashion's world cities, Oxford, Berg.

CALLON, Michel \& LAW, John. (2005), "On qualculation, agency, and otherness". Environment and Planning D: Society and Space, 23 (5): $717-$ 733. DOI: $10.1068 / \mathrm{d} 343 \mathrm{t}$.

CALLON, Michel \& MUNIESA, Fabian. (2003), "Les marchés économiques comme dispositifs collectifs de calcul”. Réseaux, 122 (6): 189-233. DOI: $10.3917 /$ res.122.0189.

CATTANI, Antonio David. (1996), Trabalho e autonomia, Petrópolis, Vozes.

CRANE, Diana. (2011). Ensaios sobre moda, arte e globalização cultural, São Paulo, Senac.

CRANE, Diana \& BOVONE, Laura. (2006), "Approaches to material culture: the sociology of fashion and clothing". Poetics, 34 (6): 319-333. DOI: $10.1016 /$ j.poetic.2006.10.002.

DOERINGER, Peter \& CREAN, Sarah. (2006), "Can fast fashion save the US apparel industry?". Socio-Economic Review, 4 (3): 353-377. DOI: $10.1093 / \mathrm{ser} / \mathrm{mwl} 014$.

DUARTE, Luiz Fernando Dias. (1986), Da vida nervosa nas classes trabalhadoras urbanas. Rio de Janeiro, Jorge Zahar Editor.

DUBAR, Claude. (1991), La socialisation: construction des identités sociales et professionnelles. Paris, Armand Colin.

ENTWISTLE, Joanne. (2000), The fashioned body: fashion, dress and modern social theory, Cambridge/ Malden, Polity Press/Blackwell.

FLIGSTEIN, Neil. (2007), "Habilidade social e a teoria dos campos". Revista de Administração de Empresas, 47 (2): 61-80. 
FONTAINE, Laurence. (1993), Histoire du colportage en Europe, XVe-XIXe siècle, Paris, Albin Michel.

FREITAS, Patrícia Tavares de. (2013), "Bolivianos(as) por entre oficinas de costura na cidade de São Paulo: novos aspectos da dinâmica migratória no século 21", in R. Baeninger (org.), Migração internacional: por dentro do estado de São Paulo, Campinas, Núcleo de Estudos de População/ Unicamp, vol. 9, pp. 77-102.

GEERTZ, Clifford. (1978), "The bazaar economy: information and search in peasant marketing". The American Economic Review, 68 (2): 28-32.

GIUSTI, Nicoletta. (2009), Introduzione allo studio della moda. Bolonha, Il Mulino.

GODART, Frédéric. (2012), Unveiling fashion: business, culture, and identity in the most glamorous industry. Basingstoke, Palgrave Macmillan/Insead Business Press.

GUIMARÃES, Nadya Araújo \& BRITO, Murillo Marschner Alves de. (2009), "A dança das cadeiras: desemprego e segregação de percursos em São Paulo e Paris”, in N. A. Guimarães (org.), Desemprego, uma construção social: Sáo Paulo, Paris e Tóquio, Belo Horizonte, Argumentum, pp. 43-66.

GUIMARÁES, Nadya Araújo; BRITO, Murillo Marschner Alves de \& BARONE, Leonardo Silva. (2016), "Mercantilização no feminino: a visibilidade do trabalho das mulheres no Brasil". Revista Brasileira de Ciências Sociais, 31 (90): 17-38.

GUIMARÃES, Nadya Araújo; DEMAZIÈRE, Didier \& KURUMI, Sugita. (2009), "Desemprego: uma experiência biográfica”, in N. A. Guimarães (org.), Desemprego, uma construção social: São Paulo, Paris e Tóquio, Belo Horizonte, Argumentum, pp. 89-195.

HADDAD, Beatriz Sumaya Malavasi \& CASTRO, Ana Lucia de. (2019), “'Moda, eu faço a minha': a circulação de símbolos globais de moda entre grupos de baixa renda”. Contemporânea: Revista de Sociologia da UFSCar, 9 (1): 229-252. DOI: 10.4322/2316-1329.089.

HANNERZ, Ulf. (1996), Transnational connections: culture, people, places. Londres, Routledge.
INSTITUTO BRASILEIRO DE GEOGRAFIA E ESTATÍSTICA (IBGE). (2019a), Pesquisa de orçamentos familiares de 2017-2018. Rio de Janeiro, IBGE.

INSTITUTO BRASILEIRO DE GEOGRAFIA E ESTATÍSTICA (IBGE). (2019b), Pesquisa nacional por amostra de domicílios contínua. Rio de Janeiro, IBGE.

KAWAMURA, Yuniya. (2005), Fashion-ology: an introduction to fashion studies. Oxford, Berg.

LAHIRE, Bernard. (2011), L'homme pluriel: les ressorts de l'action. Paris, Pluriel.

LA PRADELLE, Michèle de. (2006), Market day in Provence. Chicago, University of Chicago Press.

LOBO, Elizabeth Souza. (1989), "Experiências de mulheres. Destinos de gênero". Tempo Social, 1 (1): 169-182.

MALAGUTI, Manoel Luiz. (2001), Crítica à razão informal: a imaterialidade do salariado. São Paulo, Boitempo/Edufes.

MEDEIROS, Marcelo \& PINHEIRO, Luana Simôes. (2018), "Desigualdades de gênero em tempo de trabalho pago e não pago no Brasil, 2013". Revista Sociedade e Estado, 33 (1): 161-187. DOI: 10.1590/s0102-699220183301007.

MEIRELES, Val. (2018), Como vendo roupas ??. Vídeo no Youtube, publicado em 27/03/2018. Disponível em: https:/www.youtube.com/ watch?v=MLpQjaNrvro. Acesso em 12/06/2020.).

PINHEIRO-MACHADO, Rosana. (2004), "A garantia soy yo": etnografia das práticas comerciais entre camelôs e sacoleiros nas cidades de Porto Alegre (Brasil) e Ciudad del Este (Paraguai). Tese de mestrado. Universidade Federal do Rio Grande do Sul, Porto Alegre.

PINHEIRO-MACHADO, Rosana. (2008), "ChinaParaguai-Brasil: uma rota para pensar a economia informal". Revista Brasileira de Ciências Sociais, 23 (67): 117-133. DOI: 10.1590/S010269092008000200009.

PIRES, Lenin dos Santos. (2011), Esculhamba, mas não esculacha! Uma etnografia dos usos urbanos dos trens da central do Brasil. Niterói, Eduff.

RABOSSI, Fernando. (2011), "Negociaçôes, associaçōes e monopólios: a política da rua em Ciudad del 
Este (Paraguai)". Etnográfica, 15 (1): 83-107. DOI: $10.4000 /$ etnografica.814.

REINACH, Simona Segre. (2005), "China and Italy: fast fashion versus prêt à porter. Towards a new culture of fashion". Fashion Theory, 9 (1): 43-56. DOI: $10.2752 / 136270405778051527$.

RIBEIRO, Gustavo Lins. (2010), "A globalização popular e o sistema mundial não hegemônico". Revista Brasileira de Ciências Sociais, 25 (74): 2138. DOI: $10.1590 /$ S0102-69092010000300002.

SCHILLER, Nina Glick \& ÇAGLAR, Ayse. (org.). (2010), Locating migration: rescaling cities and migrants. Ithaca, NY, Cornell University Press.

SILVA, Carlos Freire da. (2014), Das calçadas às galerias: mercados populares do centro de São Paulo. Tese de doutorado. Universidade de São Paulo, São Paulo.

SIMMEL, Georg. (1957), "Fashion". American Journal of Sociology, 62 (6): 541-558. DOI: $10.1086 / 222102$.

TELLES, Vera da Silva. (1992), "A experiência da insegurança: trabalho e família nas classes trabalhadoras urbanas em São Paulo". Tempo Social, 4 (1-2): 53-92. DOI: 10.1590/ts.v4i1/2.84911.

TELLES, Vera da Silva. (2001), Pobreza e cidadania. São Paulo, Editora 34/Curso de Pós-Graduação em Sociologia.

TELLES, Vera da Silva \& HIRATA, Daniel Veloso. (2010), "Ilegalismos e jogos de poder em São
Paulo". Tempo Social, 22 (2): 39-59. DOI: 10.1590/S0103-20702010000200003.

VERETA-NAHOUM, André. (2019), “The Making of a Proper Marketplace: The Politics of Infrastructure in the Night Market, São Paulo", in E. Dürr eJ. Müller (org.), The popular economy in urban Latin America: informality, materiality, and gender in commerce, Lanham, MA, Lexington Books, pp. 87-108.

WEBER, Florence. (2002), "Práticas econômicas e formas ordinárias de cálculo". Mana, 8 (2): 151-182.

WEINER, Annette B. (1989), "Why cloth? Wealth, gender, and power in Oceania", in A. B. Weiner e J. Schneider (org.), Cloth and human experience, Washington, Smithsonian Books, pp. 33-72.

WEINER, Annette B. (1992), Inalienable possessions: the paradox of keeping-while-giving. Berkeley, University of California Press.

WEINER, Annette B. \& SCHNEIDER, Jane. (1989), Cloth and human experience. Washington, Smithsonian Books.

WHITE, Harrison C. (1981), "Where do markets come from?". American Journal of Sociology, 87 (3): 517-547. DOI: 10.1086/227495.

ZARCA, Bernard. (1988), "Identité de métier et identité artisanale". Revue Française de Sociologie, 29 (2): 247-273. DOI: 10.2307/3321907.

ZELIZER, Viviana A. (2005), Purchase of intimacy. Princeton, Princeton University Press. 


\section{TECENDO UM CIRCUITO COMERCIAL A PARTIR DA FEIRA DA MADRUGADA: AS AGENCIADORAS DA MODA POPULAR BRASILEIRA}

\section{André Vereta Nahoum}

Palavras-chave: Mercados informais; Trabalho por conta própria; Identidade ocupacional; Ocupação feminina; Moda.

Este artigo analisa os trabalhos de revendedoras de itens de vestuário que distribuem ao redor do país bens comercializados na Feira da Madrugada, localizada na região central de São Paulo (SP). Discute os sentidos subjetivos atribuídos a essa atividade e o conjunto de habilidades específicas necessárias para tecer esse circuito. Vale-se, para tanto, da etnografia e de entrevistas realizadas na região. Ao distribuir as mercadorias e os símbolos da moda popular, lojistas e sacoleiras também produzem sentido para suas trajetórias pessoais, revelando um sentido de dignidade e realizaçáo em relação à atividade comercial, dependente do domínio de um conjunto de habilidades e conhecimento local, muito além das capacidades genéricas de cálculo descritas pela sociologia econômica contemporânea. Essas práticas desafiam as representaçóes apontadas pela literatura para o engajamento feminino no trabalho por conta própria e para comerciantes itinerantes em geral.

\section{WEAVING A TRADE CIRCUIT FROM THE NIGHT MARKET: BRAZILIAN POPULAR FASHION AGENTS}

\section{André Vereta Nahoum}

Keywords: Informal markets; Self-employment; Occupational identity; Female occupation; Fashion.

This article analyses the work of clothing item retailers that distribute goods sold at the Night Market (Feira da Madrugada), located in the central São Paulo region (SP) around the country. It discusses the subjective meanings attributed to this activity and the set of specific skills required to weave this circuit. To this end, it employs ethnography and interviews conducted in the region. By distributing goods and popular fashion symbols, shopkeepers and sacoleiras (traveling saleswomen) also produce meaning for their personal trajectories, revealing a sense of dignity and fulfillment in relation to the trading activity, dependent on the mastery of a set of skills and local knowledge, far beyond the generic calculus capabilities described by contemporary economic sociology. These practices challenge the representations pointed out in the literature for female engagement in self-employment and for traveling merchants in general.

\section{CIRCUIT COMMERCIAL À PARTIR DE LA FEIRA DA MADRUGADA: LES REVENDEUSES DE LA MODE POPULAIRE BRÉSILIENNE}

\section{André Vereta Nahoum}

Mots-clés: marchés informels; travail indépendant; identité occupationnelle; occupation des femmes; mode.

Cet article examine les activités des revendeuses d'articles d'habillement qui redistribuent dans tout le pays des produits achetés à la Feira da Madrugada, un marché de la région centrale de São Paulo. Sur la base de données ethnographiques et d'entretiens réalisés dans la région, il analyse les significations subjectives de ce travail ainsi que les compétences spécifiques nécessaires pour tisser ce circuit. En distribuant les marchandises et les symboles de la mode populaire, les commerçants et les démarcheuses donnent également un sens à leurs trajectoires personnelles ; le sentiment de dignité et d'accomplissement professionnel dépend de la maîtrise d'un ensemble d'habiletés et de connaissances locales, très au-delà des capacités génériques de calcul décrites par la sociologie économique contemporaine. Ces pratiques remettent en question les représentations soulignées dans la littérature sur l'engagement des femmes dans le travail indépendant et sur les travailleuses du commerce ambulant en général. 